\title{
DELITO DE OCUPACIÓN PACÍFICA DE INMUEBLES (ART. 245.2 CP). LAS ÚLTIMAS PROPOSICIONES DE LEY DE REFORMA
}

\author{
Margarita Roig Torres \\ Title: Crime of nonviolent occupation of Real Estate (art. 245.2 Cp). The last \\ reform law proposals
}

Resumen: El delito de ocupación pacífica de inmuebles del artículo 245.2 CP ha sido objeto de opiniones contrapuestas, tanto en la doctrina como en la práctica forense y esta discrepancia se ha plasmado en la interpretación de sus elementos por parte de los órganos judiciales. Esta controversia se refleja también en las Proposiciones de Ley de reforma. Frente a las propuestas despenalizadores iniciales, las presentadas en los últimos años abogan por endurecer el castigo, ante el incesante incremento de estas conductas en algunas ciudades y la alarma creada por los medios de comunicación. A ello se suma la indignación ciudadana por los problemas de convivencia que en algunos casos generan, junto a la ineficacia de la normativa actual para reintegrar el inmueble y la demanda de protección por parte de las entidades bancarias y de inversión excluidas de la nueva medida civil dirigida a la inmediata recuperación de la vivienda. Pues bien, el incremento penológico que incluyen las recientes Proposiciones de Ley vulnera el principio de prohibición de exceso, en tanto responde a motivos pragmáticos alejados de los fines preventivos que presiden el Derecho penal.

Palabras clave: ocupación de viviendas; ocupación de inmuebles; artículo 245 CP; usurpación; ocupación; okupa.

Abstract: The crime of peaceful occupation of real estate described in article $245.2 \mathrm{CP}$ has been subject to criticism, both in doctrine and in forensic practice and this discrepancy has been reflected in the interpretation of its elements by the courts. This controversy exists also in the Proposals to reform the Criminal Code. Faced with the initial decriminalizing proposals, those presented in recent years advocate hardening the punishment, given the incessant increase in these behaviors in some cities and the alarm created by the media. Added to this is the public outrage at the coexistence problems that in some cases are gener- 
ated, together with the ineffectiveness of the current regulations to reinstate the property and the demand for protection by the banking and investment entities excluded of the new civil measure aimed at the immediate recovery of housing. Well, the penological increase included in the recent law proposals violates the principle of prohibition of excess, insofar as it responds to pragmatic reasons far from the preventive purposes that govern criminal law.

Keywords: housing occupation; real estate occupation; article 245 CP; usurpation; occupation; squatter.

Sumario: 1. Planteamiento. - 1.1. La alarma social generada por la ocupación ilegal de viviendas. - 1.2. Panorama en el orden penal. - 1.3. Problemática en la jurisdicción civil. - 1.4. La nueva infracción administrativa. - 2. La tendencia restrictiva de la jurisprudencia en la aplicación del artículo 245.2 CP. - 2.1. Doctrina del TEDH: derecho del ocupante a la ponderación judicial previa al desalojo. - 2.2. La interpretación del Tribunal Supremo como punto de arranque de los límites fijados en la práctica judicial. - 2.3. Posturas discrepantes en la llamada jurisprudencia menor. - 2.3.1. Plasmación de la problemática relacionada con la ocupación. - 2.3.2. Sugerencias contrapuestas de modificación del artículo 245.2 CP. - 2.3.3. Primacía del derecho a la propiedad sobre el derecho a la vivienda. - 2.3.4. La interpretación restrictiva de los elementos típicos. 2.3.5. Consideraciones personales. - 3. Proposiciones de Ley de reforma del artículo 245.2 CP. - 3.1. Propuestas iniciales despenalizadoras. - 3.2. Proposiciones de Ley del Grupo Parlamentario Popular. - 3.3. Proposiciones de Ley del Grupo Parlamentario Ciudadanos. - 4. Conclusiones. - Bibliografía citada.

\section{Planteamiento}

\subsection{La alarma social generada por la ocupación ilegal de viviendas}

La ocupación ilícita de viviendas ha ocasionado una notable alarma social, debido en buena medida a la influencia de los medios de comunicación ${ }^{1}$, que alertan de la proliferación de estas conductas que se está produciendo en los últimos años ${ }^{2}$, aunque como suele suceder este cre-

1 Sobre la visión "distorsionada" de los ciudadanos acerca del índice de delincuencia en nuestro país, que sitúan muy por encima del real debido a la influencia de los medios de comunicación, García España, E./Díez Ripollés, J.L./PÉrez Jiménez, F./Benítez Jiménez, M.J./ Cerezo Domínguez, A., "Evolución de la delincuencia en España: análisis longitudinal con encuestas de victimización", en Revista Española de Investigación Criminológica, Artículo 2, $\mathrm{n}^{\mathrm{o}} 8$, 2010, pp. 1 y ss. (https://dialnet.unirioja.es/servlet/articulo?codigo=3187503). Puede verse una comparativa entre la criminalidad española y la europea y la percepción ciudadana sobre la situación en nuestro país en, DíEz RipolLÉs, J.L., "Algunos rasgos de la delincuencia en España a comienzos del siglo XXI", en Revista Española de Investigación Criminológica, Artículo $1, \mathrm{n}^{\circ}$ 4, 2006, pp. 1 y ss. (https://dialnet.unirioja.es/servlet/articulo?codigo=2083343).

2 En 2017 había en España entre 85.000 y 90.000 viviendas ocupadas de manera ilegal, de las cuales pertenecían a entidades financieras alrededor de un $80 \%$. Diario Expansión, 16 de abril de 2017 (https://www.expansion.com/empresas/banca/2017/04/16/58f 3af7f268e3ebc4f8b459b.html). Entre 2013 y 2018 la ocupación ilegal de viviendas creció 
cimiento no coincide plenamente con los datos oficiales ${ }^{3}$. En realidad, la mayor incidencia de esas acciones se concentra en algunas ciudades ${ }^{4}$ y no supone un fenómeno generalizado que afecte a todo el territorio nacional ${ }^{5}$. Pero una vez más, la inseguridad creada y la demanda de protección por parte de los ciudadanos ${ }^{6}$, han impulsado diversas iniciativas desde distintas instituciones jurídicas, dirigidas a frenar estas actuaciones y a agilizar la restitución del inmueble usurpado a su titular. Entre ellas, destacan las propuestas de algunos Colegios de Abogados $^{7}$ y las directrices de varias

un 58\%. Diario El Mundo, 24 de noviembre de 2019 (https://www.elmundo.es/espana/201 9/11/24/5dd97350fc6c83f63c8b45b1.html). El titular de la empresa «Desokupa», dedicada a la recuperación de viviendas, afirmaba que la ocupación ilegal durante el confinamiento motivado por la pandemia había aumentado en un 300\%. Vozpopuli, 27 de julio de 2020 (https://www.vozpopuli.com/espana/okupas-viviendas-confinamiento_0_1376262938. html). En cuanto al número de denuncias, según el Sistema Estadístico de Criminalidad, adscrito al Ministerio del Interior, en 2019 hubo 14.621 denuncias por usurpación de inmuebles, produciéndose un repunte en los primeros seis primeros meses de 2020, con un total de 7.450 denuncias. Diario Cambio 16, 27 de agosto de 2020 (https://www.cambio16. com/aumentaron-ocupaciones-ilegales-de-viviendas-durante-el-confinamiento/). Según el Ministerio del Interior, en el primer semestre de 2020 hubo 7.450 denuncias de ocupación, frente a 7.093 del mismo periodo anterior. Diario El País, 17 de septiembre de 2020 (https://elpais.com/espana/2020-09-17/interior-avala-a-la-policia-para-que-pueda).

${ }_{3}^{3}$ En cambio, los datos proporcionados por la Fiscalía General del Estado reflejan un descenso en el número de procesos penales incoados en España por el delito de usurpación de inmuebles. En el año 2015 se incoaron 27.263 procedimientos, mientras en el año 2016 tan solo 12.900, en el año 2017 la cifra descendió a 10.373, en el año 2018 a 9.693 y en el año 2019 a 9.622. En la Memoria presentada en el año 2020 —en relación con las cifras del año anterior - señala que, "el dato contrasta con la percepción social del fenómeno de la ocupación". CASAS VILla, J., "Reflexiones en torno al delito de usurpación pacífica de inmuebles", en Diario La Ley, n ${ }^{\circ}$ 9709, Sección Tribuna, 5 de octubre de 2020, pp. 1 y ss.

${ }_{4}^{4}$ En el año 2019, Barcelona sufrió 2.644 ocupaciones, siendo el total en Cataluña de 3.611, seguida de las Comunidades de Andalucía, con 1.183 ocupaciones, Madrid, con 657, Comunidad Valenciana, con 566, y Castilla-La Mancha, con 296. El Español, 17 de agosto de 2020 (https://www.elespanol.com/espana/politica/20200817/cataluna-paraisookupacion-sextuplica-numero-comunidad-madrid/513449199_0.html). Respecto a la evolución de este fenómeno en Barcelona y su incremento en los últimos años, Tutor ANTÓN, A.: "¡Barcelona okupa! Una posible historia de la okupación en Barcelona”, en Inguruak, $\mathrm{n}^{\circ}$ 68, 2020, pp. 78 y ss. (http://www.inguruak.eus/index.php/inguruak/article/ view/178/105).

5 Instrucción 1/2020, de 15 de septiembre, de la Fiscalía General del Estado, sobre criterios de actuación para la solicitud de medidas cautelares en los delitos de allanamiento de morada y usurpación de bienes inmuebles, p. 2 (https://www.icav.es/bd/archivos/archivo15831.pdf).

6 De interés sobre la influencia de la inseguridad ciudadana en la firmeza frente al delito y la relación de este fenómeno con los profundos cambios experimentados por las sociedades occidentales en las últimas décadas, el trabajo de SERrano Maíllo, A., "Una nueva prueba de la teoría de los sentimientos de inseguridad explicativa de la firmeza frente al delito", en ADPCP, Vol. LXXIII, 2020, pp. 174 y ss.

${ }^{7}$ El Ilustre Colegio de Abogados de Barcelona ha propuesto la reforma del artículo 13 LECrim y la adición de un nuevo artículo 544 sexies, para la regulación expresa de medidas cautelares que permitan al juez o tribunal que conozca de un supuesto delito del artículo 245 $\mathrm{CP}$ adoptar motivadamente la medida de desalojo en un plazo máximo de cuarenta y ocho horas desde la petición cautelar, siempre y cuando los ocupantes del inmueble no puedan probar o no presenten un título jurídico que legitime su permanencia o estancia en el mismo 
Fiscalías ${ }^{8}$, que han culminado con la Instrucción 1/2020, de 15 de septiembre, de la Fiscalía General del Estado 9 . En el plano punitivo, varios Grupos parlamentarios han presentado Proposiciones de Ley que, entre otras reformas, incluyen la del artículo 245 CP. Las últimas fueron planteadas por el Grupo Parlamentario Popular y por el Grupo Parlamentario Ciudadanos (Boletín Oficial del Congreso de los Diputados de 17 de julio de 2020).

Sin embargo, estos proyectos contrastan con la postura de la doctrina penal mayoritaria ${ }^{10} \mathrm{y}$ la de otros grupos parlamentarios ${ }^{11} \mathrm{y}$ asociaciones ${ }^{12}$,

(https://www.icaib.org/acuerdo-de-la-junta-de-gobierno-adhesion-a-la-propuesta-de-modificacion-normativa-formulada-por-el-icab-sobre-ocupacion-ilegal-de-viviendas/).

8 La Instrucción de la Fiscalía de las Illes Balears, de 10 de junio de 2019, estableció que los Cuerpos y Fuerzas de Seguridad actuarán de forma inmediata sin necesidad de solicitar medidas judiciales cuando la ocupación ilegal de un inmueble revista características de delito, desalojando a los ocupantes ilegales y practicando su detención si procede (https://www.icaib.org/wp-content/uploads/2019/06/INSTRUCCION-OCUPACION-ILEGAL-DE-INMUEBLES.pdf). Por otra parte, el Decreto del Fiscal Jefe de la Fiscalía Provincial de Valencia, de 20 de agosto de 2020, determinaba que las y los fiscales deberán, tras la concreta valoración del supuesto concreto, solicitar la adopción de la medida cautelar de desalojo, al abrigo del artículo 13 LECrim, en el delito del artículo 245.2 CP (https://confilegal.com/wp-content/uploads/2020/08/Decreto-Ocupación-Ilegal-Inmuebles.pdf).

${ }^{9}$ La Fiscalía General del Estado insta a los y las fiscales a solicitar la medida cautelar de desalojo en el artículo 245.2 CP. Instrucción 1/2020, de 15 de septiembre..., cit., pp. 9 y ss.

10 Puede verse, Borja Jiménez, E., en González Cussac, J.L. (coord.), Derecho penal. Parte especial, Tirant lo Blanch, Valencia, 2019, p. 397; FernándeZ APARICIO, J.M., "Comentario al artículo 245 párrafo 2o", en Diario La Ley, Sección Doctrina, Tomo 4, 1997, p. 7; Gallego Soler, J.I., en Corcoy Bidasolo, M./Mir Puig, S. (dirs.): Comentarios al Código penal. Reforma LO 1/2015 y LO 2/2015, Tirant lo Blanch, Valencia, 2015, p. 851; MARTíNEZ García, A.S., en Gómez Tomillo, M., Comentarios prácticos al Código penal. Delitos contra el patrimonio y socieconómicos, Tomo III, Aranzadi, Navarra, 2015, p. 145; Mestre Delgado, E., en Lamarca Martínez, C. (coord.), Delitos. Parte especial del Derecho penal, Dykinson, Madrid, 2020, p. 373; MuÑoz Conde, F., Derecho penal. Parte especial, Tirant lo Blanch, Valencia, 2017, p. 370; Quintero Olivares, G., La reforma penal de 2010: análisis y comentario, Aranzadi, Navarra, 2010, p. 211; Robles Planas, R./Pastor Muñoz, N., en Silva SÁnchez, J.M. (dir.)/Ragués I Vallès, R. (coord.), Lecciones de Derecho penal. Parte especial, Atelier, Barcelona, 2015, p. 279; Serrano Gómez, A./Serrano Maíllo, A., Derecho penal. Parte especial, 11 edición, Dykinson, Madrid, 2006, p. 403; y TerRadillos Basoco, J. M., "Las reformas penales españolas de 2003: valoración político-criminal”, en Nuevo Foro Penal, no 67, 2005, p. 81. También Vives ANTÓN y GONZÁLEZ CuSSAC advertían que se trataba de un tipo creado para dar respuesta a la escasez de vivienda, o de viviendas accesibles. VIVES ANTÓN, T.S./ GonZález Cussac, J.L., en Vives Antón, T.S. (coord.), Comentarios al Código penal de 1995, Vol. II, Tirant lo Blanch, Valencia, 1996, p. 1207. No obstante, ManZANARES SAMANIEGO pone de relieve los inconvenientes de tiempo y dinero que supondría la remisión a los órdenes civil y administrativo. Manzanares Samaniego, J.L., Comentarios al Código penal (Tras las Leyes Orgánicas 1/2015, de 30 de marzo y 2/2015, de 30 de marzo), La Ley, Madrid, 2016, p. 881. Ampliamente, sobre las propuestas despenalizadoras, SERRANO-PIEDECASAS FERNÁNDEZ, J.R., "La usurpación”, en Cuadernos de Derecho Judicial, XIII, 2004, pp. 2 y 11.

11 Sobre las Proposiciones de Ley Orgánica para la despenalización del apartado 2 del artículo 245 CP, JiméNez PARís, J.M., "Desahucio exprés contra la ocupación de viviendas", en Diario La Ley, Sección Doctrina, no 9262, 19 de diciembre de 2018, p. 4.

${ }_{12}$ Resolución del Congreso de Jueces para la Democracia en Santander, días 7, 8 y 9 de noviembre 1996, acerca de la criminalización de los llamados «okupas». Propuesta de Montserrat Comas de Argemir, Estrella Blanes y Joaquín Bayo. “Jueces para la Democracia 
que han venido reivindicando la despenalización de las conductas previstas en el artículo 245.2 CP, consistentes en la ocupación sin la autorización debida, de un inmueble, vivienda o edificio ajenos que no constituyan morada, o en mantenerse en ellos contra la voluntad de su titular ${ }^{13}$. A juicio de este sector, se trata de actos propios del campo civil y su tipificación es contraria al principio de intervención mínima ${ }^{14}$.

En efecto, a mi modo de ver, no hay una diferencia sustancial entre esas acciones y la del precarista que se niega a abandonar la vivienda pese a los requerimientos del propietario, o incluso la del arrendatario que no paga el alquiler y se mantiene en ella. El elemento que las distingue es la existencia del consentimiento inicial del propietario en estos casos, frente a su ausencia en la ocupación ilícita, pero en los tres se priva al titular de la facultad de uso y disfrute, que es el objeto de tutela en el artículo 245.2 CP. De manera que, al igual que los demás supuestos, la restitución del bien podría resolverse en la vía civil, aplicándose además la sanción administrativa que se prevé solo para la ocupación realizada contra la voluntad del propietario o poseedor legítimo ${ }^{15}$.

Por eso, me parece importante analizar las razones que llevan a los citados Grupos Parlamentarios a instar la modificación del artículo 245 CP.

Pues bien, las Proposiciones de Ley recogen tipos agravados no contemplados específicamente en la regulación actual, en concreto, la ocupación mediante el uso de fuerza en las cosas, la intervención de mediadores que se lucran facilitando la usurpación, las conductas realizadas por miembros de organizaciones criminales y la utilización del inmueble para actividades delictivas. Sin embargo, los fines

solicita al Parlamento Español, a través de su Presidente, la inmediata derogación de este precepto, y solicita de los poderes públicos, que en cumplimiento del artículo 47 CE promuevan las condiciones necesarias y pertinentes para hacer efectivo el derecho de todo ciudadano a una vivienda digna y adecuada, removiendo los obstáculos que impidan o dificulten la igualdad entre los ciudadanos para su acceso" (http://www.juecesdemocracia.es/2017/06/19/ resolucion-acerca-los-llamados-okupas-m-comas-e-blanes-j-bayo/).

13 Esta norma fue introducida en el Código penal de 1995 para poder castigar la mayoría de ocupaciones ilícitas deshabitadas, puesto que no tenían encaje en el artículo 245.1 CP, que requiere violencia o intimidación, y tampoco en el delito de allanamiento de morada. López Garrido, D./García Arán, M., El Código penal de 1995 y la voluntad del legislador. Comentario al texto y al debate parlamentario, Madrid, 1996, p. 133.

14 Sobre la vulneración del carácter fragmentario y subsidiario del Derecho penal y del principio de intervención mínima puede verse, BAucElls I LlaDós, J., La ocupación de inmuebles en el Código penal de 1995, Tirant lo Blanch, Valencia, 1998, pp. 49 y 50.

15 De hecho, como pone de manifiesto SIERRA GABARDA, la difícil frontera entre el ilícito civil y el ilícito penal que se plantea en algunos casos, como los incumplimientos contractuales y el delito de estafa, desaparece por completo en el caso de la ocupación de inmuebles, de forma que el uso de uno u otro cauce ya no depende tanto de la configuración técnica del supuesto de hecho, sino de la mayor celeridad que ofrezca una u otra vía al propietario desposeído. SIERRA GABARDA, R., "Ocupación y confusión procesal”, en Diario La Ley, no 9707, Sección Tribuna, 1 de octubre de 2020, p. 3. 
esenciales que guían la reforma son, por una parte, la agilización del procedimiento para recuperar las viviendas ocupadas y, por otra, evitar la prescripción del delito del artículo 245.2 CP, ante la saturación judicial. Con estos objetivos, se introducen modificaciones procesales y se eleva la pena prevista en este precepto. De manera que, este aumento de la sanción no responde a un cambio de criterio en cuanto a la gravedad del delito, sino a motivos pragmáticos. Por otra parte, con la rápida devolución del bien no se persigue solo reintegrar a su titular la facultad de uso y disfrute, sino también afrontar los problemas de convivencia que crean dichas situaciones de ocupación irregular y, en definitiva, aplacar la inquietud social que en algunos casos provocan ${ }^{16}$. Por lo tanto, a priori el endurecimiento del castigo de este ilícito parece basarse en causas ajenas al principio de proporcionalidad que rige la regulación de la pena.

Pero conviene advertir de las consecuencias que implican esas nuevas normas que se proponen. Lo que parece un pequeño incremento de la cuantía de la multa del artículo $245.2 \mathrm{CP}$ conlleva otros efectos trascendentes. Significa una modificación en la calificación del delito, que pasa de ser leve a menos grave, con las consiguientes implicaciones que ello supone. Para empezar, si la persona condenada no pudiera pagar la cantidad impuesta, lo que es especialmente probable en este delito, el órgano judicial no podría sustituirla por una pena de localización permanente, sino que la responsabilidad subsidiaria quedaría reducida a la prisión o trabajos en beneficio de la comunidad. Además, esa calificación tiene importancia de cara a la reincidencia, suspensión de la pena, prescripción, cancelación de antecedentes penales, etc. Por otra parte, ya no se enjuiciaría por el procedimiento para delitos leves, ante el propio juez de instrucción, sino por el abreviado, que conlleva una segunda fase competencia del juez de lo penal, con una mayor dilación.

De esta forma, el intento de salvar algunos obstáculos procesales, como la prescripción, y de garantizar la condena de quienes ocupan ilícitamente un inmueble tiene un alcance que, a mi juicio, no han valorado los Grupos parlamentarios que proponen la reforma de ese precepto, según se desprende de las Exposiciones de Motivos de las Proposiciones de Ley.

16 Esos problemas de convivencia eran aducidos por algunos autores para justificar la necesidad de tutelar penalmente la propiedad inmobiliaria que no constituya morada, frente a los ataques subrepticios, clandestinos o realizados mediante fuerza en las cosas. JimÉNEZ PARÍs, J.M., “Desahucio exprés...”, cit., pp. 15 y 16. 


\subsection{Panorama en el orden penal}

El artículo 245.2 CP castiga la ocupación de un inmueble, vivienda o edificio ajenos ${ }^{17}$ que no constituyan morada ${ }^{18}$, o su mantenimiento en ellos, sin autorización, con una pena de multa de tres a seis meses ${ }^{19}$. Esta sanción no fue modificada por la LO 1/2015, de 30 de marzo. Sin embargo, la ley sí introdujo cambios importantes en la clasificación de las penas del artículo $33 \mathrm{CP}^{20}$ que afectaron a la gravedad de este delito. En concreto, la multa de más de dos meses era antes una pena menos grave, según el apartado 3. En cambio, a partir de la reforma, la multa de hasta

17 Sobre estos conceptos, Queralt Jiménez, J.J., Derecho penal español. Parte especial, Atelier, Barcelona, 2010, p. 446. En cuanto a la diferencia entre la noción civil de inmueble y la penal, atendiendo a la posibilidad de aprehenderlo y a su movilidad, SERRANo Gómez, A./Serrano Maíllo, A.: Derecho penal. Parte especial, cit., p. 402; y, Serrano Gómez, A./Serrano Maíllo, A./Serrano Tárraga, M.D/Vázouez González, C., Curso de Derecho penal. Parte especial, $4^{a}$ edición, Dykinson, Madrid, 2017, p. 296.

${ }_{18}$ El Tribunal Constitucional ha afirmado que "el domicilio inviolable es un espacio en el cual el individuo vive sin estar sujeto necesariamente a los usos y convenciones sociales y ejerce su libertad más íntima". STC 22/1984, de 17 de febrero (F.J.5). Además, ha concretado que "este concepto constitucional de domicilio..., es más amplio que el concepto jurídico-privado o jurídico-administrativo, ambos funcionales a otros fines distintos de la protección de la intimidad y la vida privada". STC 94/1999, de 31 de mayo (F.J.5). Son de interés, además, las SSTC 171/1999, de 27 de septiembre (F.J.9), 119/2001, de 24 de mayo (F.F.J.J.5 y 6), y, 10/2002, de 17 de enero (F.F.J.J.5, 6 y 7). En este sentido se ha pronunciado también el Tribunal Supremo: "Es de resaltar que el concepto de «domicilio" a los efectos que nos ocupan no puede ceñirse estrictamente al de lugar que sirve de morada habitual del individuo. El concepto subyacente en el artículo 18.2 CE ha de entenderse de modo amplio y flexible ya que trata de defender los ámbitos en los que se desarrolla la vida privada de las personas". STS 436/2001, de 19 de marzo (F.J.13). En esa definición se han incluido las viviendas que se ocupan de modo temporal o accidental. SSTS 731/2013, de 7 octubre (F.J.4), y, 852/2014, 11 de diciembre (F.J.3). En la doctrina, MoralEs Prats, F., "Comentario al artículo 202 del Código penal", en Quintero Olivares, G. (dir.)/MoraLES Prats, F. (coord.), Comentarios al Código penal español, Tomo I, $7^{\mathrm{a}}$ edición, Aranzadi, Navarra, 2016 (E-book). Teniendo en cuenta la postura constitucional sobre el domicilio, BORJA JIMÉNEZ define la morada a partir de dos elementos: material (edificio, lugar delimitado físicamente con el mundo exterior) y espiritual (la proyección de ese espacio acotado por la personalidad humana). BoRJA JIMÉNEZ, E.: "El bien jurídico protegido en el delito de allanamiento de morada", en VVAA: Estudios jurídicos en memoria del Prof. Dr. D. José Ramón Casabó Ruiz, Vol I, Universitat de València, 1997, p. 271. Puede verse una síntesis del concepto de morada en la doctrina en, ARIAS EIBE, M.J., "La inviolabilidad del domicilio: dimensión constitucional y protección penal”, en Diario La Ley, Sección Doctrina, Tomo IV, 2001, pp. 6 y ss. Extensamente sobre el tema, SANZ MorÁn, Á., El allanamiento de morada, domicilio de personas jurídicas y establecimientos abiertos al público, Tirant lo Blanch, Valencia, 2006, pp. 40 y ss.

${ }_{19}$ Llama la atención sobre la escasa gravedad de este delito que se desprende de la multa prevista, Barja De Quiroga, J., en Barja De Quiroga, J./Granados Pérez, C., Manual de Derecho penal. Parte especial. Tomo II. (Contestaciones al programa de Derecho Penal Parte Especial para acceso a las carreras Judicial y Fiscal. Temas 27 a 63), Aranzadi, Navarra, 2018 (E-book).

20 Hernández García, J./Ramírez Ortiz, J.L., "Las consecuencias procesales de la reforma", en Quintero Olivares, G. (dir.), Comentario a la reforma penal de 2015, Aranzadi, Navarra, 2015, pp. 241 y ss. 
tres meses (inclusive) es, según el apartado 4, una pena leve. De manera que, de acuerdo con el artículo 13, apartado $3 \mathrm{CP}$ las conductas reguladas en el artículo $245.2 \mathrm{CP}$ constituyen hoy un delito leve y no menos grave como antes de la reforma. Así pues, aunque el mínimo es de tres meses, el artículo 13, apartado 4 CP establece que cuando la pena, por su extensión, pueda considerarse como leve y como menos grave, el delito se considerará, en todo caso, como leve. Por consiguiente, cualquier ilícito castigado con una pena mínima de multa de tres meses es leve. Esto ha hecho que la inmensa mayoría de las ocupaciones ilegales de viviendas, en tanto se realizan sin violencia o intimidación ${ }^{21}$, sean hoy infracciones menores ${ }^{22}$.

Esta variación, que seguramente pasó desapercibida al legislador ${ }^{23}$, tiene repercusiones relevantes para la aplicación del artículo 245.2 CP, especialmente en cuanto a la prescripción del delito y de la pena, que ya no es a los cinco años como antes de la reforma sino al año (arts. 131 y $133 \mathrm{CP}$ ). De modo que, dada la acumulación de asuntos en nuestros órganos judiciales y el consiguiente retraso judicial, muchos de esos hechos no pueden juzgarse por haber prescrito.

A su vez, esa calificación como delito leve introducía ciertas trabas procesales que dificultaban el fin primordial del agraviado de recobrar el inmueble.

Este ilícito pasaba a juzgarse por el procedimiento para delitos leves, regulado en los artículos 962 y ss LECrim y en el marco de este proceso se han suscitado dudas sobre la posibilidad de acordar la medida cautelar de desalojo ${ }^{24}$.

21 Baucells I Lladós, en cambio, mantenía una interpretación particular del artículo $245.2 \mathrm{CP}$, entendiendo que es un tipo privilegiado respecto del 245.1 CP, del que se diferencia solo porque los bienes inmuebles objeto del primero son los que no han estado ocupados nunca o los que están definitivamente abandonados, pero requiriendo en ambas figuras igual uso de violencia o intimidación. BAUCELLS I LLADÓs, J., La ocupación de inmuebles..., cit., pp. 132 y ss; y, Baucells Lladós, J., en CóRdoba RodA, J./Garcia Arán, M., Comentarios al Código Penal. Parte Especial, Tomo I, Marcial Pons, Madrid 2004, p. 725.

22 Gasca López, A.I., “Análisis de elementos diferenciadores de delitos menos graves y leves”, en Cuadernos Digitales de Formación, n 45, 2017, p. 18.

23 González Rus, J.J., "Secuelas «colaterales» no pretendidas de la LO 1/2015, de 30 de marzo, de reforma del Código Penal”, en Diario La Ley, no 8553, Sección Tribuna, 3 de junio de 2015, p. 1; y González Rus, J.J., en Morillas Cueva, L. (dir.), Estudios sobre el Código penal reformado (Leyes Orgánicas 1/2015 y 2/2015), Dykinson, Madrid, 2015, p. 30. Por el contrario, Rodríguez LAINZ entiende que se aprovechó la reforma del Código Penal de 2015 para, sin tocar una sola coma del artículo 245.2 CP ni de un tipo penal tan relacionado con éste, como es el de la defraudación de fluido eléctrico y análogas del artículo 255 $\mathrm{CP}$, convertir tales infracciones de menos graves a leves, a través de la citada modificación penológica. Rodríguez LAINZ, J.L., “¿Es jurídicamente posible el desalojo inmediato de viviendas objeto de un delito leve de ocupación ilegal?”, en Diario La Ley, n 9701, Sección Doctrina, 22 de septiembre de 2020, p. 2.

24 Hidalgo García, J., "Hacia un protocolo de actuación integral en materia de ocupaciones de viviendas y bienes inmuebles", en Diario La Ley, n 9719, Sección Tribuna, 20 de octubre de 2020, pp. 1 y 2 . 
Así pues, el artículo 13 LECrim permite adoptar aquellas medidas cautelares que el órgano judicial estime necesarias para proteger a los ofendidos o perjudicados y por este cauce podría decretar el lanzamiento y la devolución del inmueble a su poseedor legítimo ${ }^{25}$.

Pese a ello, un sector doctrinal se ha manifestado contrario a la aplicación de esa medida a los delitos leves ${ }^{26}$. En la práctica, como pone de relieve la Fiscalía General del Estado, pese a que en su opinión no existe impedimento para ordenarla, muchos órganos judiciales no la acuerdan, al no existir una previsión expresa ${ }^{27}$. Por eso, en la Instrucción 1/2020, ha establecido que los y las fiscales deberán solicitarla en el delito del artículo $245.2 \mathrm{CP}$, cuando concurran los elementos necesarios ${ }^{28}$.

Además, al tratarse de un delito leve es problemática la posibilidad de detener a los ocupantes cuando se niegan a dejar el inmueble ${ }^{29}$.

El artículo 495 LECrim dispone que "No se podrá detener por simples faltas, a no ser que el presunto reo no tuviere domicilio conocido ni diese fianza bastante, a juicio de la autoridad o agente que intente detenerle".

Pero, como es sabido, las faltas fueron suprimidas por la LO 1/2015, de 30 de marzo, y esta ley no es clara en este punto. En su Disposición

25 Artículo 13 LECrim: "Se consideran como primeras diligencias la de consignar las pruebas del delito que puedan desaparecer, la de recoger y poner en custodia cuanto conduzca a su comprobación y a la identificación del delincuente, la de detener, en su caso, a los presuntos responsables del delito, y la de proteger a los ofendidos o perjudicados por el mismo, a sus familiares o a otras personas, pudiendo acordarse a tal efecto las medidas cautelares a las que se refiere el artículo 544 bis o la orden de protección prevista en el artículo 544 ter de esta ley".

26 Véase, Magro Servet, V., “¿Delito de ocupación de morada (art. 245.2 CP) o allanamiento de morada (art. 202 CP) ¿Medidas civiles o medidas cautelares penales de expulsión?, en Diario La Ley, n ${ }^{\circ}$ 9680, Sección Doctrina, 23 de julio de 2020, p. 4. A favor de su adopción, en cambio, MARTí MARTí, J., "La protección del Derecho penal frente a la ocupación de los bienes inmuebles por colectivos "ocupas»", en Diario La Ley, n 7999, Sección Tribuna, 11 de enero de 2013, p. 3; y, PÉrez Daudí, V./SÁnchez García, J., "La protección del propietario frente a los actos de ocupación ilegal de un bien inmueble”, en Diario La Ley, $\mathrm{n}^{\circ}$ 9008, Sección Documento on-line, 26 de junio de 2017, p. 7.

27 Por eso, propone "introducir un inciso en el artículo. 13 LECrim a fin de que se recoja de forma expresa la posibilidad de acordar como medida cautelar el reintegro en la posesión con carácter provisional a los legítimos titulares de los bienes muebles o inmuebles sustraídos o usurpados". Memoria de la Fiscalía General del Estado de 2017. Capítulo VI. Propuestas de reformas legislativas. Derecho procesal penal (https://www.fiscal.es/memorias/memoria2017/FISCALIA_SITE/index.html).

28 Instrucción 1/2020, de 15 de septiembre.., cit., p. 15.

29 En la doctrina admite la detención por delitos leves, HeRnÁNDEZ García, J./RAMírez ORTIZ, J.L., "Las consecuencias procesales de la reforma", cit., p. 255. En cambio, la niegan, Faraldo Cabana, P., Los delitos leves. Causas y consecuencias de la desaparición de las faltas, Tirant lo Blanch, Valencia 2016, p. 200; RAMón RIVAS, E., "El delito de ocupación ilegal no violenta de viviendas”, en Estudios Penales y Criminológicos, Vol. XL, 2020, p. 409, cita 8; y, PÉrez Daudí, V./SÁnchez García, J., “La protección del propietario...", cit., p. 13. 
adicional segunda («Instrucción y enjuiciamiento de los delitos leves»), establece lo siguiente: "La instrucción y el enjuiciamiento de los delitos leves cometidos tras la entrada en vigor de la presente Ley se sustanciarán conforme al procedimiento previsto en el Libro VI de la vigente Ley de Enjuiciamiento Criminal, cuyos preceptos se adaptarán a la presente reforma en todo aquello que sea necesario. Las menciones contenidas en las leyes procesales a las faltas se entenderán referidas a los delitos leves" 30 . Sin embargo, este último inciso admite distintas interpretaciones, pudiéndose entender referido a toda la legislación procesal, o solo a las normas que regulan el procedimiento para delitos leves ${ }^{31}$.

En mi opinión, la alusión genérica a las "leyes procesales" inclina hacia la primera solución. Por lo tanto, dado que el artículo 495 LECrim prohíbe detener por simples faltas, esta disposición es igualmente aplicable a los delitos leves.

Ahora bien, esta noma excepciona los supuestos en los que el presunto reo no tuviere domicilio conocido y por esta vía cabría detener a los ocupantes que no presentan ningún título que les legitime para usar el inmueble, si no tienen domicilio conocido.

Pese a ello, en la práctica la policía procede a la detención cuando interviene en el momento de la ocupación ${ }^{32}$, al tratarse de un delito flagrante $^{33}$, pero si ya se ha efectuado con anterioridad o si hay personas vulnerables remite el atestado al juzgado ${ }^{34}$.

Esta solución ha sido avalada por la Instrucción 6/2020 de la Secretaría de Estado de Seguridad por la que se establece el Protocolo de actuación de las Fuerzas y Cuerpos de Seguridad del Estado ante la ocupación ilegal de inmuebles. En ella se dispone que, al tratarse de un delito leve no cabe la detención, salvo en caso de delito flagrante. Sin embargo, sí es

30 La cursiva es añadida.

31 IzQuierdo TÉllez, C., “¿Se puede detener por delito leve?”, en Diario La Ley, nº 8582, Sección Tribuna, 14 de julio de 2015, pp. 1 y ss.

32 Artículo 490 LECrim: “Cualquier persona puede detener: ..."al delincuente in fraganti”.

Artículo 492 LECrim: "La Autoridad o agente de Policía judicial tendrá obligación de detener: 1. A cualquiera que se halle en alguno de los casos del artículo 490”.

33 Artículo 795.1.1 ${ }^{a}$ LECrim:... "Se considerará delito flagrante el que se estuviese cometiendo o se acabare de cometer cuando el delincuente sea sorprendido en el acto. Se entenderá sorprendido en el acto no sólo al delincuente que fuere detenido en el momento de estar cometiendo el delito, sino también al detenido o perseguido inmediatamente después de cometerlo, si la persecución durare o no se suspendiere mientras el delincuente no se ponga fuera del inmediato alcance de los que le persiguen. También se considerará delincuente in fraganti aquel a quien se sorprendiere inmediatamente después de cometido un delito con efectos, instrumentos o vestigios que permitan presumir su participación en él”.

34 Pérez Daudí, V./Sánchez García, J.: “La okupación de bienes inmuebles...”, cit., pp. 3 y 4 . 
posible cuando el presunto reo carezca de domicilio conocido conforme al artículo 495 LECrim $^{35}$.

En definitiva, la policía no realiza el desalojo inmediato, sino que la decisión queda al criterio del juez o tribunal. Y, como se ha visto, en la práctica muchos órganos judiciales son reacios a disponerlo como medida cautelar. Por eso, la Instrucción 1/2020, de la Fiscalía General del Estado, ha impulsado su petición por parte de los y las fiscales. Además, respecto a la actuación policial, la Instrucción 6/2020 ha aclarado que los agentes pueden detener sin mandamiento judicial si el autor no tiene domicilio conocido.

Por otra parte, el artículo 964 LECrim permite a los jueces acordar el sobreseimiento de las actuaciones por delito leve a instancia del Ministerio Fiscal. De manera que, tras recibir el atestado o denuncia podría ponerse fin al proceso si el autor accede a abandonar la vivienda. Sin embargo, la Circular 1/2015 de la Fiscalía General del Estado ${ }^{36}$ determina respecto al artículo $245.2 \mathrm{CP}^{37}$ que, se interesará siempre la prosecución de la causa y la celebración de juicio por tratarse de hechos que se configuraban como delito menos grave hasta la reforma penal de $2010^{38}$.

En consecuencia, la devolución del inmueble se acuerda en la sentencia, que puede ser recurrida, suspendiéndose en este caso la ejecución del fallo. Esto hace que, en el ámbito penal, el plazo para la restitución de la vivienda se dilate notablemente ${ }^{39}$.

Además, el juzgador acude a veces a distintos mecanismos para dictar sentencia absolutoria, como la falta de prueba respecto a la voluntad de permanencia, la existencia de un contrato no meridianamente falso ${ }^{40}$, la carencia de las condiciones mínimas para que el inmueble sea habita$\mathrm{do}^{41}$, el hecho de no haber sido utilizado por el propietario y, en menor medida, el estado de necesidad ${ }^{42}$.

35 Instrucción 6/2020 de la Secretaría de Estado de Seguridad por la que se establece el Protocolo de actuación de las Fuerzas y Cuerpos de Seguridad del Estado ante la ocupación ilegal de inmuebles, pp. 15 y 16 (https://www.elindependiente.com/wp-content/ uploads/2020/09/INSTRUCCIO\%CC\%81N-SES.pdf).

36 Circular 1/2015, de 19 de junio, de la Fiscalía General del Estado, sobre pautas para el ejercicio de la acción penal en relación con los delitos leves tras la reforma operada por la $L O$ 1/2015 (https://www.boe.es/buscar/doc.php?coleccion=fiscalia\&id=FIS-C-2015-00001\&tn=2).

37 Circular 1/2015, de 19 de junio..., cit., p. 33.

38 Este delito fue reformado por la LO 5/2010, de 22 de junio.

39 Habitualmente ese plazo supera un año, alcanzando los dos años en muchos casos. Magro Servet, “¿Delito de ocupación de morada (art. 245.2 CP)...”, cit., p. 6.

40 Algunas sentencias han absuelto al imputado porque ha quedado acreditado que había pagado a un tercero para vivir en el inmueble. PÉrez DaUdí/Sánchez García, "La protección del propietario...”, cit., p. 3.

41 Instrucción del Fiscal Superior de la Fiscalía de les Illes Balears, de 10 de junio de 2019 (https://www.icaib.org/wp-content/uploads/2019/06/INSTRUCCION-OCUPACIONILEGAL-DE-INMUEBLES.pdf).

42 Incluso los jueces de instrucción archivan a veces las diligencias por entender que se trata de una cuestión civil. MAGro SERVET, V., "Soluciones ante la presencia de okupas, 


\subsection{Problemática en la jurisdicción civil}

En el orden civil, la Ley 5/2018, de 11 de junio, de modificación de la Ley $1 / 2000$, de 7 de enero, de Enjuiciamiento Civil ${ }^{43}$, tampoco ha conseguido el propósito expresado de dar una respuesta ágil y rápida al fenómeno de la ocupación, descargando así a la jurisdicción penal que debe actuar como ultima ratio ${ }^{44}$. A tenor de este argumento, me parece evidente que el legislador albergaba ciertas reticencias respecto a la tipificación del delito del artículo 245.2 CP.

La ley reformaba el artículo 250.1.4 LEC $^{45}$, permitiendo al demandante solicitar en el juicio verbal la inmediata recuperación de la plena posesión de la vivienda. Pero su puesta en práctica ha evidenciado varias deficiencias.

En primer lugar, el precepto no es aplicable a las personas jurídicas privadas con ánimo de lucro, como las entidades bancarias o de inversión, titulares de un número importante de los inmuebles usurpados ${ }^{46}$.

En segundo lugar, dicha medida ha de ser solicitada expresamente por el demandante, sin que pueda adoptarse de oficio.

pisos patera y defraudación de fluido eléctrico en las comunidades de vecinos. ¿Cómo actuar ante alquileres irregulares u ocupación de viviendas y los enganches ilegales de luz a vecinos?”, en Diario La Ley, no 8225, Sección Tribuna, 9 de enero de 2014, p. 5.

${ }_{43}$ Esta ley modificó los artículos 150, 250, 437, 441 y 444 LEC. Puede verse un comentario en García OrRuÑo, A., "Cuestiones procesales que plantea la Ley 5/2018, de 11 de junio, en materia de ocupación ilegal”, en Boletín Juezas y Jueces para la Democracia, 19 de diciembre de 2018, pp. 4 y ss (http://www.juecesdemocracia.es/wp-content/ uploads/2018/12/Boletin-Privado-19.pdf); y, SCHUMANN BARRAGÁN, G., "El proceso de tutela sumaria de la posesión por ocupación ilegal de viviendas introducido por la Ley 5/2018. Su naturaleza jurídica y algunas implicaciones prácticas", en Diario La Ley, no 9264, Sección Tribuna, 21 de septiembre de 2018, pp. 2 y ss.

${ }_{44}$ Según indica la Exposición de Motivos: "Si bien la legislación vigente permite acudir a la vía penal, articulada con frecuencia al amparo de los artículos 245.2 y concordantes del Código penal como delito de usurpación, esta forma de tutela jurídica responde a una respuesta propia del Derecho penal, es decir, de «ultima ratio», por lo que no comporta ni puede comportar una solución general que trascienda o sustituya los mecanismos civiles para la tutela de los derechos posesorios".

45 Artículo 250 LEC: "1. Se decidirán en juicio verbal, cualquiera que sea su cuantía, las demandas siguientes:...4. ${ }^{\circ}$ Las que pretendan la tutela sumaria de la tenencia o de la posesión de una cosa o derecho por quien haya sido despojado de ellas o perturbado en su disfrute.

Podrán pedir la inmediata recuperación de la plena posesión de una vivienda o parte de ella, siempre que se hayan visto privados de ella sin su consentimiento, la persona física que sea propietaria o poseedora legítima por otro título, las entidades sin ánimo de lucro con derecho a poseerla y las entidades públicas propietarias o poseedoras legítimas de vivienda social".

46 Puede leerse una crítica en, Jiménez París, "Desahucio exprés...", cit., p. 5; Perea GonZÁLEZ, Á., "La recuperación de la vivienda ocupada ilegalmente: un examen del proceso del artículo 250.1.4 de la Ley de Enjuiciamiento Civil”, en Diario La Ley, no 3, 2019, p. 15; y, SCHUMANn BARRAGán, G., "El proceso de tutela sumaria de la posesión...", cit., p. 5. Lo destaca también la STC -Pleno- 32/2019, de 28 de febrero de 2019 (F.J.2). 
En tercer lugar, cuando se efectúa esa petición, el juez ha de requerir a los ocupantes ${ }^{47}$ para que aporten, en el plazo de cinco días, título que justifique su situación posesoria ${ }^{48}$. Y aquí es donde surgen los principales escollos para la reintegración inmediata.

El Tribunal Constitucional se pronunció sobre la Ley 5/2018, de 11 de junio, en la Sentencia de Pleno 32/2019, de 28 de febrero, donde avaló esta norma por entender que los cauces procesales existentes no ofrecían una respuesta satisfactoria al creciente problema de la ocupación ilegal de viviendas ${ }^{49}$. Para declarar su constitucionalidad se basa principalmente en la igualdad de armas procesales que otorga a las partes. En este sentido afirma que cualquier título que aporte el demandado le sirve para enervar la acción ejercitada a través de ese procedimiento especial ${ }^{50}$.

Por lo tanto, la exigencia de que se presente un título hace insuficiente la mera justificación verbal ${ }^{51}$. Pero quien ocupa la vivienda entrega a menudo documentos dirigidos a retrasar el desalojo, habitualmente un título falso (contrato de alquiler o carta del propietario), y en ocasiones la acreditación del pago de gastos comunitarios, o de recibos de agua, luz o gas ${ }^{52}$. También es frecuente el cambio de cerradura para demostrar que

47 La Ley 5/2018, de 11 de junio, facilitó el régimen de notificaciones, al prever en el artículo 441 bis LEC que la notificación de la demanda se hará a quien se encuentre habitando la vivienda, pero se podrá hacer a los ignorados ocupantes de la misma. Esta disposición se debió a la propuesta del Sr. Sancho Margallo. Comparecencia de D. Ignacio Sancho Gargallo en la Comisión de Justicia del Congreso de los Diputados. Diario de Sesiones del Congreso de los Diputados, núm. 250, 6 de junio de 2017, p. 12 (http://www. congreso.es/public_oficiales/L12/CONG/DS/CO/DSCD-12-CO-250.PDF).

48 Artículo 441 LECrim. Casos especiales en la tramitación inicial del juicio verbal: “1 bis... Si el demandante hubiera solicitado la inmediata entrega de la posesión de la vivienda, en el decreto de admisión de la demanda se requerirá a sus ocupantes para que aporten, en el plazo de cinco días desde la notificación de aquella, título que justifique su situación posesoria. Si no se aportara justificación suficiente, el tribunal ordenará mediante auto la inmediata entrega de la posesión de la vivienda al demandante, siempre que el título que se hubiere acompañado a la demanda fuere bastante para la acreditación de su derecho a poseer. Contra el auto que decida sobre el incidente no cabrá recurso alguno y se llevará a efecto contra cualquiera de los ocupantes que se encontraren en ese momento en la vivienda.

En todo caso, en la misma resolución en que se acuerde la entrega de la posesión de la vivienda al demandante y el desalojo de los ocupantes, se ordenará comunicar tal circunstancia, siempre que se hubiera otorgado el consentimiento por los interesados, a los servicios públicos competentes en materia de política social, para que, en el plazo de siete días, puedan adoptar las medidas de protección que en su caso procedan”.

49 STC -Pleno- 32/2019, de 28 de febrero de 2019 (F.J.3).

50 STC -Pleno- 32/2019, de 28 de febrero de 2019 (F.J.7).

51 Magro Servet, V., "Análisis de los títulos de oposición de los «okupas» ante demandas por la vía del art. 441 bis $2^{\circ}$ LEC”, en Diario La Ley, n 9419, Sección Doctrina, 21 de mayo de 2019, pp. 8 y ss.

52 García OrRuño, A., "Cuestiones procesales que plantea la Ley 5/2018, de 11 de junio...”, cit., p. 15; y, RuIz BlaY, G., "La ineficacia práctica del artículo 245 del Código Penal para obtener el desalojo de un inmueble usurpado", en Diario La Ley, n ${ }^{\circ}$ 8429, Sección Dossier, 26 de noviembre de 2014, p. 7. 
se tiene llave y la realización de enganches ilegales a la luz para poseerla, alegando que la casa es propia ${ }^{53}$. Si se dan estas circunstancias, el juez no acude al incidente de reposición inmediata, sino que se celebra el juicio $^{54}$ a fin de examinar los títulos aportados por ambas partes ${ }^{55}$.

En cuarto lugar, si entre quienes ocupan el inmueble hay personas vulnerables, se debe comunicar la orden de lanzamiento a los servicios sociales para que adopten las medidas oportunas, lo que supone buscarles alojamiento y con ello demorar la devolución ${ }^{56}$.

De esta forma, también en la jurisdicción civil el procedimiento para recuperar la vivienda suele prolongarse bastantes meses desde la interposición de la demanda ${ }^{57}$.

\subsection{La nueva infracción administrativa}

La LO 4/2015, de 30 de marzo, de Protección de la Seguridad Ciudadana, introdujo en su artículo 37.7 como infracción leve "la ocupación de cualquier bien inmueble, vivienda o edificio ajenos, o la permanencia en ellos, en ambos casos contra la voluntad de su propietario, arrendatario o titular de otro derecho sobre el mismo, cuando no sean constitutivas de infracción penal" 58 .

53 De La Mata Barranco, N.J., "El inexistente plazo de 48 horas: la policía no tiene límite de tiempo para intervenir en una okupación”, en Diario El País, 1 de septiembre de 2020 (https://verne.elpais.com/verne/2020/09/01/articulo/1598938999_179935.html); MAGRO SERVET, V., "Ocupación ilegal de inmuebles: ¿delito del art. 245.2 CP o precario?, en La Ley Penal, nº 85, septiembre 2011, pp. 1 y 2; y, PÉrez Daudí, V./Sánchez García, J., "La okupación de bienes inmuebles y la protección efectiva del poseedor legítimo", en Diario La Ley, no 9687, Sección Tribuna, 2 de septiembre de 2020, p. 3.

54 Sobre este proceso, CARRILlo FuILlERAT, D.A., "Procedimientos que llevan aparejado el lanzamiento", en Diario La Ley, no 9289, Sección Doctrina, 30 de octubre de 2018, p. 9.

55 STC -Pleno- 32/2019, de 28 de febrero de 2019 (F.J.3).

56 García OrRuño, "Cuestiones procesales que plantea la Ley 5/2018, de 11 de junio...”, cit., p. 4; MAGRo SERVET, “¿Delito de ocupación de morada (art. 245.2 CP)...”, cit., p. 3; y, PÉrez Daudí, V./SÁNChez GARcía, “La okupación de bienes inmuebles...”, cit., p. 11.

57 Dice Magro Servet que este proceso suele durar al menos siete u ocho meses. MAGRO SERVET, “¿Delito de ocupación de morada (art. 245.2 CP)...”, cit., p. 4.

58 El artículo 39 sanciona estas conductas con una multa de 100 a 600 euros. Por su parte, el artículo 45 declara expresamente el carácter subsidiario del procedimiento sancionador respecto del penal y establece que no podrán sancionarse los hechos que lo hayan sido penal o administrativamente cuando se aprecie identidad de sujeto, de hecho y de fundamento. Recuerda el carácter de ultima ratio que corresponde a esta rama del Derecho, PARejo Alonso, L., "La deriva de las relaciones entre los Derechos administrativo y penal. Algunas reflexiones sobre la necesaria recuperación de su lógica sistemática”, en Documentación Administrativa, Madrid, n² 284-285, 2009, pp. 273 y ss. 
Pues bien, la incorporación de esta norma creaba problemas de deslinde con el delito del artículo $245.2 \mathrm{CP}^{59}$. Ante la ausencia de elementos axiológicos diferenciadores ${ }^{60}$, la distinción se basa en el grado de afección del bien jurídico protegido ${ }^{61}$, puesto que en los dos casos se tutela la posesión material. A mi juicio, la diferencia reside en la vocación de permanencia que, como se verá, es necesaria en esa figura y que no requiere la infracción administrativa. Es decir, si una persona se limita a entrar y tomar posesión del inmueble incurrirá en el ilícito administrativo y si se instala en él con la pretensión de permanecer de modo prolongado realizará el delito.

En mi opinión, la creación de esta infracción, que no existía cuando el legislador de 1995 decidió incluir el ilícito del artículo 245.2 CP, es un elemento más para defender su despenalización ${ }^{62}$. El principio de prohibición de exceso aconseja comprobar si la sanción administrativa es efectiva para disuadir a los ocupantes, o si de verdad es necesaria la multa penal ${ }^{63}$.

No obstante, para recuperar la vivienda el poseedor legítimo ha de acudir a la jurisdicción civil. El artículo 49 prevé la posibilidad de adoptar medidas provisionales, que en todo caso han de ser proporcionadas a la naturaleza y gravedad de la infracción. A continuación, enumera una serie medidas especialmente adecuadas, pero entre ellas no se encuentra el desalojo del inmueble, vivienda o edificio ilegalmente ocupados. La ocupación en sí no afecta a la seguridad ciudadana y la tutela de la posesión corresponde al orden civil.

59 Guillén Álvarez, I., "Estudio y análisis jurídico de la nueva Ley Orgánica 4/2015, de protección de la seguridad ciudadana”, en Diario La Ley, nº 8633, Sección Doctrina, 27 de octubre de 2015, p. 20.

${ }^{60}$ No obstante, en el artículo $245.2 \mathrm{CP}$ se tutela al propietario y en el ilícito administrativo, además, al arrendatario y a los titulares de otros derechos.

61 CASAS Villa, "Reflexiones en torno al delito de usurpación...", cit., p. 7.

62 Algunos juzgados han entendido que el artículo 37.7 supone una derogación tácita del delito del artículo 245.2 CP. Álvarez TeJERo, A., "La usurpación delito leve o infracción administrativa. "A vueltas con el art.245.2 del Código Penal»", en Lefebvre-El Derecho, $\mathrm{n}^{\circ}$ 2, 13 de julio 2016 (https://elderecho.com/la-usurpacion-delito-leve-o-infraccion-administrativa-a-vueltas-con-el-art-245-2-del-codigo-penal-2).

63 Como señala Berdugo De LA TORRE, el carácter de ultima ratio del Derecho penal debería conllevar que esté subordinado a la insuficiencia de otros medios menos gravosos para el individuo de que dispone el Estado. Por ello, la subsidiariedad es una exigencia que debe ser afrontada por el legislador. En este sentido, es difícil pensar en un bien jurídico que solo sea defendible por el Derecho penal. El encontrar bienes jurídicos cuya protección es afrontada exclusivamente por el Ordenamiento jurídico-punitivo, no es sino una prueba de la falta de respeto del legislador por este principio y de una política legislativa que responde a la utilización de otros criterios distintos al de la racionalidad. Berdugo De La Torre, I., "El Derecho penal”, en Demetrio Crespo, E. /Rodríguez Yagüe, C. (coords.): Curso de Derecho penal. Parte general, $3^{\text {a }}$ edición, Ediciones Experiencia, Barcelona, 2016, pp. 1 y ss. 


\title{
2. La tendencia restrictiva de la jurisprudencia en la aplicación del artículo 245.2 CP
}

\author{
2.1. Doctrina del TEDH: derecho del ocupante a la \\ ponderación judicial previa al desalojo
}

La Corte europea ha declarado preferente el derecho a la propiedad respecto al derecho a la vivienda, debiéndose reintegrar a su titular con la mayor celeridad cuando se ha visto despojado de ella sin justo título. Ahora bien, si el ocupante ha hecho del inmueble su domicilio, le atribuye unas garantías singulares, facultándole para oponerse a la expulsión, estableciendo que los tribunales han de valorar la proporcionalidad y racionalidad de esta medida.

En efecto, en el caso Casa Di Cura Valle Fiorita S.R.L. c. Italia, de 13 de diciembre de $2018^{64}$, la Corte rechaza las razones esgrimidas por las autoridades nacionales para no ejecutar la orden judicial de desalojar cautelarmente el inmueble de la sociedad recurrente. En primer lugar, la ausencia de soluciones alternativas de alojamiento para los ocupantes, debido a las dificultades económicas del municipio. En segundo lugar, el impacto mediático y los problemas de orden público que podía acarrear la expulsión de varias decenas de personas ${ }^{65}$. En este sentido, declara que la falta de recursos no justifica el incumplimiento de una decisión judicial, ni siquiera por carecer de otras viviendas ${ }^{66}$. En consecuencia, señala que el transcurso de varios años sin ejecutar la resolución violó el derecho a un proceso equitativo del artículo $6 \mathrm{CEDH}^{67}$.

De manera que el TEDH prima el derecho de propiedad ${ }^{68}$ y establece que la administración debe proceder al lanzamiento, aunque no pueda proporcionar cobijo a las personas que no tengan medios económicos para sufragarlo.

64 (https://hudoc.echr.coe.int/eng\#[ «languageisocode»:[«ITA»], »appno»:[«67944/13»], »documentcollectionid2»:[«CHAMBER»],»itemid»:[«001-189044»]].

65 Caso Casa Di Cura Valle Fiorita S.R.L. c. Italia, de 13 de diciembre de 2018 (F.J.51).

66 Caso Casa Di Cura Valle Fiorita S.R.L. c. Italia, de 13 de diciembre de 2018 (F.J.53).

67 El TEDH declara que las garantías de equidad, publicidad y celeridad, que comprenden el derecho a un proceso equitativo del artículo $6 \mathrm{CEDH}$, no solo se refieren al procedimiento sino también a la ejecución. Caso Casa Di Cura Valle Fiorita S.R.L. c. Italia, de 13 de diciembre de 2018 (F.F.J.J.46 y 54).

68 La Corte examina la falta de ejecución de la decisión judicial a la luz de la regla general contenida en el primer párrafo del artículo 1 del Protocolo $\mathrm{n}^{\circ} 1$, que prevé el derecho al respeto de la propiedad. Caso Casa Di Cura Valle Fiorita S.R.L. c. Italia, de 13 de diciembre de 2018 (F.J.55). 
Ahora bien, en el caso Winterstein y otros c. Francia, de 17 octubre $2013^{69}$, precisa que el concepto de "domicilio" en el sentido del artículo 8 $\mathrm{CEDH}$, que recoge el derecho al respeto de la vida privada y familiar, no se limita al legalmente establecido, sino que depende de las circunstancias de hecho, en particular de si existen vínculos suficientes y continuos con el lugar habitado ${ }^{70}$.

A partir de aquí, indica que quien se encuentre en riesgo de perder su domicilio tiene derecho a que la proporcionalidad de la expulsión sea examinada por un tribunal independiente. Para valorarla, el juzgador debe tener en cuenta si el domicilio se ha fijado legalmente o de modo ilegal, pues en este caso el afectado está en una posición menos fuerte. Pero señala también que, si no se dispone de alojamiento alternativo, o si hay personas vulnerables, la interferencia es más grave. En el caso enjuiciado, al no darse esa posibilidad de revisión se vulneró el artículo $8 \mathrm{CEDH}^{71}$.

No obstante, el TEDH no dice que estas circunstancias determinen el mantenimiento de quienes no pueden acceder a otro domicilio. Tan solo subraya la facultad del perjudicado de que la decisión la evalúe un juez con detalle y responda razonadamente.

Por lo tanto, antepone el derecho a la propiedad y, en situaciones particularmente sensibles, establece la obligación procesal de motivar minuciosamente el fallo.

Pero, a mi juicio, esto tiene relevancia de cara a la medida cautelar de expulsión, puesto que, según esta tesis de la Corte, no podrá adoptarse si el inmueble se ha convertido en domicilio y quien reside en él se opone a abandonarlo.

Esa garantía esencial, del enjuiciamiento judicial cuando se cuestiona la obligación de abandonar la vivienda, la ha reiterado el TEDH en otras sentencias, como las de los casos Buckland v. The United Kingdom, de 18 de septiembre de $2002^{72}$ y Yordanova and others v. Bulgaria, de 24 de abril de $2012^{73}$.

69 (https://hudoc.echr.coe.int/eng\#[“fulltext”:["Winterstein”],"documentcollectionid2”: [“GRANDCHAMBER”,"CHAMBER”],"itemid”:[“001-126910”]].

70 Caso Winterstein y otros c. Francia, de 17 octubre 2013 (F.J.141).

71 Caso Winterstein y otros c. Francia, de 17 octubre 2013 (F.J.F.J.142 a 160).

72 "La pérdida del hogar es la forma más extrema de injerencia en el derecho al respeto del hogar. Toda persona en riesgo de una injerencia de esta magnitud debería, en principio, poder hacer que la proporcionalidad de la medida sea determinada por un tribunal independiente a la luz de los principios pertinentes del artículo 8 de la Convención, sin perjuicio de que, conforme al Derecho interno, su derecho a la ocupación ha llegado a su fin" (F.J.64) (https://hudoc.echr.coe.int/eng\#[“fulltext”:[“CASE OF BUCKLAND v. THE UNITED KINGDOM”],”documentcollectionid2”:[“GRANDCHAMBER”, ,CHAMBER”],”it emid”:[“001-113129”]\}.

73 "Dado que la pérdida del hogar es la forma más extrema de injerencia en el derecho previsto en el artículo 8 al respeto del propio hogar, cualquier persona que corra el riesgo 


\subsection{La interpretación del Tribunal Supremo como punto de arranque de los límites fijados en la práctica judicial}

Para aplicar el artículo 245.2 CP, el Tribunal Supremo ha requerido que la ocupación afecte a la facultad de posesión del propietario, lo que supone la vocación de permanencia por parte del autor, la ausencia de título que justifique su uso y la voluntad contraria del titular. Algunos de estos elementos han sido interpretados de forma distinta por los órganos judiciales.

En la STS 1318/2004, de 15 de noviembre, se refirió a ese delito, señalando que fue introducido en el CP de 1995 a fin de sancionar las conductas de los llamados "ocupas" ${ }^{74}$. La propia terminología utilizada refleja que estos actos todavía no habían alcanzado la envergadura que luego los convertiría en un verdadero problema social, cuando los integrantes del movimiento "okupa" 75 , que propugna la ocupación de viviendas o locales deshabitados, usurparon un elevado número por motivos reivindicativos más que económicos. A ellos se sumarían las realizadas por los conocidos popularmente como “ocupas”, quienes sí actúan llevados por su situación de penuria ${ }^{76}$. El tribunal confirma la absolución de quien figuraba como titular registral y usaba unos inmuebles, al no haber acreditado la recurrente ningún título para fundar su derecho, ni haber realizado actos de posesión, como tampoco el pago de algún tipo de contribución o impuesto por las propiedades ${ }^{77}$.

En la STS 143/2011, de 2 de marzo, se desestima el motivo que denunciaba la inaplicación del artículo 245.2 CP. El tribunal precisa que este ilícito admite la ocupación por cualquier método e incluye el forzamiento de cerraduras o candados, porque lo relevante es que se

\footnotetext{
de sufrir una injerencia de esta magnitud debería, en principio, poder gozar de la proporcionalidad y razonabilidad de la medida determinada por un tribunal independiente a la luz de los principios pertinentes del artículo 8, sin perjuicio de que, conforme al Derecho interno, no tenga derecho de ocupación... Esto significa, entre otras cosas, que cuando el solicitante haya planteado argumentos relevantes sobre la proporcionalidad de la injerencia en procedimientos judiciales internos, los tribunales nacionales deben examinarlos en detalle y proporcionar las razones adecuadas" (F.J.118) (https://hudoc.echr.coe.int/eng/\# ["fulltext":["Yordanova"],"documentcollectionid2":[“GRANDCHAMBER","CHAMBER"]," itemid”:[“001-110449”]\}.

${ }^{74}$ Sobre la situación de las ocupaciones en aquellos momentos, Hernández García, J., "La protección constitucional de la vivienda y su proyección penal: especial referencia a los movimientos okupa y mobbing inmobiliario", en Cuadernos de Derecho Judicial, X, 2005, p. 19; y, Queralt Jiménez, J.J., Derecho penal español. Parte especial, cit., p. 445.

75 Según el Diccionario de la RAE, el término "okupa”, significa: "1. adj. jerg. Dicho de un movimiento radical: que propugna la ocupación de viviendas o locales deshabitados. 2. adj. jerg. Perteneciente o relativo al movimiento okupa. 3. m. y f. jerg. Miembro de un grupo okupa".

76 JimÉnEZ PaRís, “Desahucio exprés...”, cit., p. 26.

77 STS 1318/2004, de 15 de noviembre (F.J.6).
} 
trate de viviendas o locales no habitados. Argumenta que en los hechos probados no existe referencia a una ocupación en contra de la expresa y directa prohibición del titular, ni tampoco una permanencia en contra de su voluntad que, únicamente se exterioriza en la fecha de la interposición de la querella, sin haberse solicitado ninguna diligencia para recuperar la posesión hasta la vista oral ${ }^{78}$. Luego, requiere la oposición expresa del propietario en las dos modalidades típicas, sin que baste la denuncia o querella.

En mi opinión, esta interpretación no se acomoda al tenor de la norma, que solo precisa esa manifestación explícita en la segunda conducta, tipificando el mantenimiento "contra la voluntad de su titular". Además, dificulta la condena por la ocupación, que únicamente sería viable si el propietario está presente y niega la entrada o si anuncia esa voluntad contraria de otra forma, como un cartel publicado en el inmueble.

Pero fue en la STS 800/2014, de 12 de noviembre, donde el tribunal recogió los requisitos esenciales del delito del artículo $245.2 \mathrm{CP}^{79}$. Señala

78 STS 143/2011, de 2 de marzo (F.J.2).

79 "Los delitos de usurpación, tipificados en el Capítulo V del Título XIII del Código Penal de 1995, constituyen una modalidad de delitos patrimoniales que tutelan específicamente los derechos reales sobre bienes inmuebles.

En ellos el bien jurídico protegido es el patrimonio inmobiliario, y como delitos patrimoniales la lesión del bien jurídico requiere que se ocasione un perjuicio al titular del patrimonio afectado, que es el sujeto pasivo del delito.

La modalidad delictiva específica de ocupación pacífica de inmuebles, introducida en el Código penal de 1995 en el número $2^{\circ}$ del artículo 245, requiere para su comisión los siguientes elementos:

a) La ocupación, sin violencia o intimidación, de un inmueble, vivienda o edificio que en ese momento no constituya morada de alguna persona, realizada con cierta vocación de permanencia.

b) Que esta perturbación posesoria puede ser calificada penalmente como ocupación, ya que la interpretación de la acción típica debe realizarse desde la perspectiva del bien jurídico protegido y del principio de proporcionalidad que informa el sistema penal (Art.49.3 ${ }^{\circ}$ de la Carta de Derechos Fundamentales de la Unión Europea). Desde ambas perspectivas la ocupación inmobiliaria tipificada penalmente es la que conlleva un riesgo relevante para la posesión del sujeto pasivo sobre el inmueble afectado, que es lo que dota de lesividad y significación típica a la conducta, por lo que las ocupaciones ocasionales o esporádicas, sin vocación de permanencia o de escasa intensidad, son ajenas al ámbito de aplicación del tipo.

c) Que el realizador de la ocupación carezca de título jurídico que legitime esa posesión, pues en el caso de que hubiera sido autorizado para ocupar el inmueble, aunque fuese temporalmente o en calidad de precarista, la acción no debe reputarse como delictiva, y el titular deberá acudir al ejercicio de las acciones civiles procedentes para recuperar su posesión.

d) Que conste la voluntad contraria a tolerar la ocupación por parte del titular del inmueble, bien antes de producirse, bien después, lo que especifica este artículo al contemplar el mantenimiento en el edificio "contra la voluntad de su titular", voluntad que deberá ser expresa.

e) Que concurra dolo en el autor, que abarca el conocimiento de la ajenidad del inmueble y de la ausencia de autorización, unido a la voluntad de afectación del bien jurídico 
que el bien jurídico protegido es el patrimonio inmobiliario $\mathrm{y}$, a continuación, define esos elementos.

Destaca, en primer lugar, la exigencia de una verdadera "ocupación”. Esta expresión se interpreta desde la óptica del bien jurídico protegido y del principio de proporcionalidad, precisando que se cree un riesgo relevante para la posesión del sujeto pasivo ${ }^{80}$. Desde esta perspectiva se excluyen las ocupaciones ocasionales o esporádicas, sin vocación de permanencia o de escasa intensidad. Como se verá, los tribunales han atribuido a este presupuesto un alcance diferente, exigiendo algunos la permanencia durante un tiempo para realizar el delito, mientras otros consideran suficiente una estancia breve con la pretensión de continuidad.

Por otra parte, el autor ha de carecer de título legítimo para la posesión, pues si ha sido autorizado para ocupar el inmueble, aunque sea temporalmente o en calidad de precarista, la controversia se ha de resolver en la vía civil.

Además, es necesario que conste la voluntad contraria del propietario a tolerar la ocupación, bien antes de producirse, o bien después, en cuyo caso deberá ser expresa. Así pues, a diferencia de la sentencia anterior, en este caso el Tribunal Supremo declara que esta oposición explícita solo es necesaria en la segunda modalidad típica. La duda surge sobre si en ese supuesto basta la denuncia o querella o si es necesario un requerimiento de desalojo. En este sentido, como se comprobará, existe también discrepancia entre los órganos judiciales.

Finalmente, el dolo conlleva la voluntad de afectar al bien jurídico protegido, es decir, de perturbar la posesión del titular de la finca ocupada. Nótese que se considera sujeto pasivo al propietario y no a quienes poseen el derecho de uso en virtud de otros títulos.

En el supuesto enjuiciado se afirma la concurrencia de esos presupuestos. Los condenados ocuparon una finca rústica militar durante dieciocho días. Dice el tribunal que el acto simbólico de protesta social (atípico) se convierte en delictivo porque los acusados habían configurado la ocupación como indefinida, acordando no abandonar la finca hasta que fuesen obligados a ello por la fuerza ${ }^{81}$. El fin de la denuncia se cumple con el simbolismo y la publicidad de la ocupación, y no justifica en absoluto su carácter indefinido ni una persistencia que perturba de

tutelado por el delito, es decir la efectiva perturbación de la posesión del titular de la finca ocupada” (F.J.3).

80 A estos efectos, precisa que el titular puede ser la administración pública, con independencia de que disponga de otros procedimientos para recuperar sus inmuebles. STS 800/2014, de 12 de noviembre (F.J.5).

81 STS 800/2014, de 12 de noviembre (F.J.4). 
modo muy relevante y desproporcionado las facultades que competen al titular dominical ${ }^{82}$.

En consecuencia, el tribunal declara atípico el hecho inicial del asentamiento y afirma la ofensividad de la conducta cuando los autores deciden prolongarlo con carácter indefinido y se establecen de forma permanente. Por lo tanto, teniendo en cuenta que excluye las ocupaciones esporádicas o de poca intensidad, parece necesario un tiempo mínimo de estancia con la intención de continuidad.

En el ATS 114/2017, 6 de julio ${ }^{83}$, se inadmite el recurso contra la sentencia que condenó a la acusada por un delito del artículo 245.2 CP. Indica el tribunal que la voluntad en contra de la ocupación quedó patente mediante la declaración de la testigo (hija de la propietaria ya fallecida), quien afirmó que acudió al piso, aproximadamente un mes y medio antes de la entrada y registro, que le abrió la acusada y que, cuando le dijo que era la propietaria, le cerró la puerta. Añade que lo determinante en este ilícito es la falta de autorización para entrar y permanecer en la vivienda y la exclusión del disfrute, incluso potencial, de su propietario.

De esta forma, el tribunal confirma que no es necesaria la prohibición inicial expresa del titular, e incluso en un momento posterior deduce su voluntad contraria al mantenimiento del gesto de la ocupante, sin exigir tampoco esa prohibición explícita. Igualmente, deja claro que no se ha de privar de la posesión material actual sino de la posibilidad de usar el bien.

\subsection{Posturas discrepantes en la llamada jurisprudencia menor}

2.3.1. Plasmación de la problemática relacionada con la ocupación

Antes de analizar los elementos del artículo 245.2 CP muchos órganos judiciales se refieren al contexto y a los problemas que rodean a este ilícito.

En este sentido, algunas resoluciones declaran que "entre los fenómenos sociales que ha provocado la actual crisis económica se encuentra lo

82 STS 800/2014, de 12 de noviembre (F.J.11).

83 En la STS 341/2017, de 12 de mayo, se absolvió al acusado, estimando el recurso de revisión planteado, al ser dos los condenados por un hecho que solo pudo realizar uno. En los hechos probados que basaron la condena en el artículo $245.2 \mathrm{CP}$, consta que dicho acusado accedió sin autorización a una vivienda de una entidad bancaria y se mantuvo en ella hasta que se decretó su desalojo. Se dice que, actuando con el propósito de usarla de forma indefinida como vivienda, entró a través de una ventana. Una vez dentro, cambió la cerradura de la puerta y se instaló en el piso; al carecer de suministro de energía eléctrica, realizó una conexión a la deriva individual de otra vivienda. Se destaca, pues, la intención de utilizarla de manera ilimitada, presupuesto esencial para la realización del tipo. 
que generalmente se conoce como el «movimiento okupa», que ha sido útil para sensibilizar socialmente de un problema real de muchas familias que se encuentran en una situación de exclusión y marginación social”. Además, se pronuncian de un modo llamativamente amplio sobre las circunstancias del mercado de trabajo, afirmando "la difícil situación laboral y económica actual, con insensata precarización salarial, y, la acentuada, $y$, en ocasiones bochornosa y vergonzante brecha de desigualdad social y económica, y de discriminación salarial de la mujer". Ponen de relieve que "el empeoramiento de esta situación de emergencia social y la limitación o escasez de las ayudas que reciben las personas afectadas contrastan con los ingentes beneficios obtenidos por entidades financieras y empresas de suministros" ${ }^{84}$. Reflejan la situación de precariedad económica que muchas veces concurre en sus autores ${ }^{85}$ y la aplicación del tipo que se viene haciendo incluso en casos de extrema penuria ${ }^{86}$. Como apuntan, esta realidad "ha generado en los últimos tiempos un intenso debate social debido a la frecuencia con que resultan habitados, sin consentimiento de sus titulares, inmuebles por terceras personas carentes de recursos económicos" 87 . Incluso, algunos tribunales critican la intervención del Derecho penal, señalando que "la criminalización de dicha conducta se debe a una concreta opción de política criminal que no tiene en cuenta la colisión que provoca con las normas del Derecho civil que ofrecen una protección del derecho posesorio de inmuebles" 88 .

Pero en dirección opuesta, los órganos judiciales dan cuenta también de ciertos actos ilícitos que en algunos casos van ligados a las ocupaciones ilegales de viviendas. La existencia de personas y grupos que proporcionan contratos ficticios de alquiler con el fin de dificultar el desalojo, así como conductas chantajistas frente a los propietarios para liberar los inmuebles, protagonizadas a menudo por grupos organizados. Pero, además, aluden a otras realidades, como las empresas que ofrecen sus servicios a los titulares para recuperar sus propiedades y la preocupación de los vecinos que ven cómo se invaden pisos y locales que se destinan a actividades ilícitas. Apuntan, incluso, los problemas de convivencia, insalubridad, suciedad, ruidos, peleas, etc., que padece el vecindario ${ }^{89}$.

Curiosamente, estos efectos colaterales, que en ocasiones perjudican a los propios ocupantes, se citan en las últimas Proposiciones

84 AAP de Barcelona 269/2020, de 11 de mayo (F.J.7).

85 SAP de Tenerife 274/2019, de 2 de septiembre (F.J.3), y, SAP de Tenerife 278/2019, de 26 de septiembre (F.J. Único).

86 SAP de Madrid 216/2020, de 16 de junio (F.J.2)

87 SAP de Tenerife 274/2019, de 2 de septiembre (F.J.3).

88 SAP de Barcelona 623/2019, de 2 de octubre (F.J.2), y, SAP de Barcelona 186/2020, de 11 de marzo (F.J.1).

89 AAP de Barcelona 240/2020, de 11 de mayo (F.F.J.J.6 y 9), y, AAP de Barcelona 269/2020, de 11 de mayo (F.F.J.J.6 y 9). 
de Ley como fundamento para modificar y endurecer las penas del artículo $245.2 \mathrm{CP}$.

\subsubsection{Sugerencias contrapuestas de modificación del artículo 245.2 CP}

A la vista de la problemática que rodea a este ilícito, algunas resoluciones se pronuncian sobre las alternativas planteadas y apuntan distintas vías de solución.

El punto de arranque del debate reside en la procedencia o no de despenalizarlo, teniendo en cuenta, por una parte, el incesante incremento de las ocupaciones en algunas ciudades, y, por otra, que el campo natural para la tutela de la posesión es el civil ${ }^{90}$.

A partir de estas premisas, algunos tribunales se muestran contrarios a suprimirlo y advierten del "efecto llamada" que esta decisión podría tener y el consiguiente aumento de comportamientos de esta índole. En su lugar, proponen potenciar la medida cautelar de desalojo de los artículos 13 y 544 y ss. LECrim ${ }^{91}$, e incluso reformar el artículo 245.2 CP, para elevar este delito de la categoría de leve a menos grave, de modo que se facilite esa expulsión inmediata ${ }^{92}$.

Frente a los reparos que suscita esta norma desde el principio de proporcionalidad $^{93}$, recuerdan que fue introducida en un Código penal de nuevo cuño adaptado a las exigencias de un Estado social y democrático de Derecho, por lo que cabe presumir que responde a los valores proclamados por el artículo $1 \mathrm{CE}^{94}$.

En cambio, otros órganos se decantan por descriminalizar estas conductas, en la medida en que puede darse una respuesta menos invasiva a través de los procesos civiles que permiten el desalojo ${ }^{95}$.

No obstante, desde ambas perspectivas, se reconoce la necesidad de deslindar este delito de los supuestos propios del Derecho civil y destacan que no pueden dejar de aplicarlo en virtud del principio de intervención

90 SAP de Las Palmas 18/2020, de 24 de enero (F.J.2).

91 AAP de Barcelona 240/2020, de 11 de mayo (F.J.10), y, AAP de Barcelona 269/2020, de 11 de mayo (F.J.10).

92 AAP de Barcelona 240/2020, de 11 de mayo (F.F.J.J.6 y 15), AAP de Barcelona 269/2020, de 11 de mayo (F.J.6), y, SAP de Las Palmas 131/2020, de 21 de mayo (F.J.2).

93 Recoge jurisprudencia sobre las condiciones para cumplir el principio de proporcionalidad, JIMÉNEZ SEGADO, C.: “¿Es delictiva la ocupación pacífica y sin autorización de un inmueble, vivienda o edificio ajenos que no constituyan morada?”, en La Ley Penal, $\mathrm{n}^{\circ} 102$, Sección Consulta de los suscriptores, La Ley 577/2013, pp. 1 y 2.

94 SAP de Valladolid 221/2019, de 2 de septiembre (F.J.1), SAP de Burgos de 17 de enero de 2000 (F.J.2), SAP de Madrid 103/2020, de 5 de marzo (F.J.3), y, SAP de Madrid 115/2020, de 12 de marzo (F.J.2).

95 SAP de Barcelona 767/2019, de 22 de noviembre (F.J.3), y, SAP de Barcelona 224/2020, de 7 de abril (F.J.2). 
mínima, en tanto esta regla se dirige al legislador y no rige en la actuación judicial, donde impera el principio de legalidad ${ }^{96}$. Por tanto, se advierte con claridad que es un delito cuestionado en la práctica forense.

Justamente, es al fijar esos criterios determinantes de la aplicación de esta figura donde divergen las respuestas de los órganos judiciales. En todo caso, parten de los requisitos señalados por el Tribunal Supremo, pero mientras algunos los interpretan de un modo amplio para facilitar la condena, otros mantienen un sentido restrictivo a fin de posibilitar la absolución.

\subsubsection{Primacía del derecho a la propiedad sobre el derecho a la vivienda}

En las situaciones de penuria económica por parte de las personas que ocupan una vivienda ajena, se ven implicados, por una parte, el derecho a la propiedad privada del artículo 33.1 CE y, por otra, el derecho a una vivienda digna y adecuada del artículo $47 \mathrm{CE}^{97}$. Sin embargo, este precepto dispone que los poderes públicos promoverán las condiciones necesarias y establecerán las normas pertinentes para hacer efectivo ese derecho a la vivienda. En consecuencia, los tribunales generalmente anteponen el derecho a la propiedad privada, pues corresponde a la administración proporcionar alojamiento a quien carece de recursos para sufragarlo ${ }^{98}$.

No obstante, el artículo 33.2 CE dispone que la función social de la propiedad privada delimitará su contenido, de acuerdo con las leyes ${ }^{99}$. De modo que abre la puerta a posibles expropiaciones, para satisfacer un interés superior ${ }^{100}$.

96 SAP de Madrid 693/2017, de 23 de octubre (F.J.2), SAP de Madrid 503/2019, de 28 de junio (F.J.2), SAP de Valladolid 221/2019, de 2 de septiembre (F.J.1), SAP de Tenerife 274/2019, de 2 de septiembre (F.J.3), SAP de Valencia 408/2019, de 2 de septiembre (F.J.4), SAP de Barcelona 523/2019, de 2 de septiembre (F.J.2), SAP de Sevilla 409/2019, de 1 de octubre (F.J.1), SAP de Toledo 74/2019, de 2 de diciembre (F.J.2), SAP de Málaga 451/2019, de 27 de diciembre (F.J.2), SAP de Barcelona 224/2020, de 7 de abril (F.J.3), AAP de Barcelona 269/2020, de 11 de mayo (F.J.6), SAP de Madrid 160/2020, de 25 mayo (F.J.2), y, SAP de Madrid 216/2020, de 16 de junio (F.J.2).

97 Ampliamente, Herranz Castillo, R., "Desobediencia civil, ocupación y derecho a la vivienda", en Actualidad Jurídica Aranzadi, no 435, 2000, pp. 1 y ss.

98 SAP de Madrid 160/2020, de 25 mayo (F.J.2).

99 Al respecto, Mangas Campos, Á., "La interpretación del artículo 245.2 del Código Penal y el activismo judicial”, en Diario La Ley, no 8672, Sección Doctrina, 28 de diciembre de 2015 , pp. 3 y ss.

100 "En efecto, la referencia a la «función social» como elemento estructural de la definición misma del derecho a la propiedad privada o como factor determinante de la delimitación legal de su contenido pone de manifiesto que la Constitución no ha recogido una concepción abstracta de este derecho como mero ámbito subjetivo de libre disposición o señorío sobre el bien objeto del dominio reservado a su titular, sometido únicamente en su ejercicio a las limitaciones generales que las Leyes impongan para salvaguardar los legítimos derechos o intereses de terceros o del interés general. Por el contrario, la Constitución reconoce un derecho a la propiedad privada que se configura y protege, ciertamente, como un haz de facultades individuales sobre las cosas, pero también, y al mismo tiempo, como 
En cuanto al artículo $245 \mathrm{CP}$, los tribunales han precisado que esa función social hace referencia a intereses de la colectividad, no de un concreto ciudadano por muy necesitado que esté ${ }^{101}$. Pese a ello, como después se verá, algunos órganos judiciales han entendido que a veces el inmueble sí presta ese servicio cuando quien lo ocupa se encuentra en estado de pobreza y el titular no ha hecho ningún uso de él.

Ahora bien, el derecho a la vivienda puede prevalecer sobre el de propiedad si concurren los presupuestos del estado de necesidad del artículo 20.5 CP.

Pero esta circunstancia tiene una escasa aplicación práctica, puesto que los supuestos de necesidad que no pueden solventarse por medios menos gravosos que la comisión del delito son excepcionales ${ }^{102}$.

Se rechaza esta eximente, como completa e incompleta, si no se prueba la existencia de una situación económica precaria ${ }^{103}$ o desesperada ${ }^{104}$, actual o inminente ${ }^{105}$. A estos efectos, los tribunales precisan que no basta el hecho de estar en paro, incluso sin percibir un subsidio de desempleo, si no se acredita un estado de indigencia. En alguna resolución se llega a exigir que el ocupante evidencie que carece de los elementos de primera necesidad, de modo que corre peligro su vida o la de sus allegados ${ }^{106}$.

un conjunto de deberes y obligaciones establecidos, de acuerdo con las Leyes, en atención a valores o intereses de la colectividad, es decir, a la finalidad o utilidad social que cada categoría de bienes objeto de dominio esté llamada a cumplir. Por ello, la fijación del «contenido esencial» de la propiedad privada no puede hacerse desde la exclusiva consideración subjetiva del derecho o de los intereses individuales que a éste subyacen, sino que debe incluir igualmente la necesaria referencia a la función social, entendida no como mero límite externo a su definición o a su ejercicio, sino como parte integrante del derecho mismo. Utilidad individual y función social definen, por tanto, inescindiblemente el contenido del derecho de propiedad sobre cada categoría o tipo de bienes". STC 37/1987, de 26 de marzo (F.J.2).

101 En este sentido se pronuncia, la SAP de Córdoba 76/2000, de 9 de octubre, que estimó el recurso contra la sentencia de instancia, que aplicó la circunstancia de estado de necesidad como eximente completa en el caso de una familia que había ocupado un local comercial de la Junta de Andalucía, apreciándola la Audiencia como incompleta. Como señala QUINTERo OLIVARES, es posible que el autor crea que, por carecer de vivienda, está legitimado para ocupar la que encuentre vacía, partiendo del derecho a la vivienda digna, reconocido en el artículo $47 \mathrm{CE}$. Sin embargo, al igual que sucede con los restantes derechos sociales-constitucionales no es posible admitir una facultad subjetiva para ejercitarlos. Quintero Olivares, G.: “Comentario al artículo 245 del Código penal”, en Quintero Olivares, G. (dir.)/Morales Prats, F. (coord.): Comentarios al Código penal español, Tomo I, $7^{\text {a }}$ edición, Aranzadi, Navarra, 2016 (E-book).

102 Ampliamente, Mirapeix Lacasa, N., "Las ocupaciones de inmuebles por motivos de necesidad”, en Revista Electrónica de Ciencia Penal y Criminología, 20-22, 2018, pp. 3 y ss.

103 SAP de Madrid 503/2019, de 28 de junio (F.J.2), SAP de Valladolid 221/2019, de 2 de septiembre (F.J.1), SAP de Tenerife 274/2019, de 2 de septiembre (F.J.3), SAP de Sevilla 364/2019, de 9 de septiembre (F.J.1), SAP de Sevilla 409/2019, de 1 de octubre (F.J.2), y, SAP de Madrid 693/2017, de 23 de octubre (F.J.2).

104 SAP de Madrid 676/2019, de 19 de diciembre (F.J.3).

105 SAP de Badajoz 242/2019, de 30 de diciembre (F.J.2).

106 SAP de Madrid 216/2020, de 16 de junio (F.J.2). 
Además, es preciso que haya agotado todos los cauces legales para obtener una vivienda, ya sean familiares o de cualquier otra índole ${ }^{107}$. En particular, ha de haber recurrido a la asistencia social y a las ayudas institucionales en fecha anterior a la ocupación ${ }^{108}$. En realidad, este es el principal escollo para aplicar la eximente, puesto que muchas personas que sí atraviesan una penosa situación económica no acuden a los organismos públicos antes de usar una vivienda que encuentran deshabitada.

Por consiguiente, solo se aprecia en casos extraordinarios ${ }^{109}$, cuando se ha solicitado ayuda a la administración y se dan las condiciones de urgencia y extrema pobreza ${ }^{110}$.

107 Como es sabido, aunque el artículo 20.5 CP no lo exige expresamente, en la doctrina y en la jurisprudencia se precisa, para aplicar la eximente, que no haya un medio menos gravoso de evitar el mal. Cobo Del Rosal, M./Vives Antón, T.S., Derecho penal. Parte general, Tirant lo Blanch, Valencia, 1999, p. 520; Marín De Espinosa Ceballos, E., en Zugaldía Espinar, J.M. (dir.)/Moreno Torres-Herrera, M.R. (coord.): Fundamentos de derecho penal. Parte general, Tirant lo Blanch, Valencia, 2015, p. 314; MIR PUIG, S., Derecho penal. Parte general, Reppertor, Barcelona, 2015, p. 714; Muñoz CondE, F./García ArÁN, M., Derecho penal. Parte general, Tirant lo Blanch, Valencia, 2015, p. 354; y, OrTs Berenguer, E./GonzÁlez Cussac, J.L., Compendio de Derecho penal. Parte general, Tirant lo Blanch, Valencia, 2019, p. 399.

108 SAP de Burgos de 17 de enero de 2000 (F.J.3), SAP de Madrid 693/2017, de 23 de octubre (F.J.2), SAP de Madrid 54/2019, de 22 de enero (F.J.1), SAP de Madrid 503/2019, de 28 de junio (F.J.2), SAP de Valladolid 221/2019, de 2 de septiembre (F.J.1), SAP de Tenerife 274/2019, de 2 de septiembre (F.J.3), SAP de Valencia 408/2019, de 2 de septiembre (F.J.4), SAP de Madrid 517/2019, de 2 de septiembre (F.J.2), SAP de Sevilla 364/2019, de 9 de septiembre (F.J.1), SAP de Tenerife 278/2019, de 26 de septiembre (F.J. Único), SAP de Sevilla 409/2019, de 1 de octubre (F.J.2), SAP de Madrid 655/2019, de 2 de octubre (F.J.3), SAP de Madrid 724/2019, de 11 de noviembre (F.J.3), SAP de Tenerife 383/2019, de 15 de noviembre (F.J.1), SAP de Madrid 809/2019, de 30 de noviembre (F.J.3), SAP de Madrid 676/2019, de 19 de diciembre (F.J.3), SAP de Málaga 451/2019, de 27 de diciembre (F.J.2), SAP de Badajoz 242/2019, de 30 de diciembre (F.J.2), SAP de Valladolid 26/2020, de 12 de febrero (F.J.2), SAP de les Illes Balears 54/2020, de 25 de junio (F.J.3), SAP de Madrid 266/2020, de 9 de julio (F.J.2), y, SAP de Madrid 377/2020, de 10 de julio (F.J.3).

109 Romeo Casabona, C.M./Sola Reche, E./Boldova Pasamar, M.A., Derecho Penal. Parte especial, Comares, Granada, 2016, p. 356.

110 Así, en la SAP de Lleida 431/2019, de 11 de noviembre, se aplicó a la demandada, que había acudido al Departament de Treball, Afers Socials i Famílies de la Generalitat de Catalunya, sin constar que dispusiera de ingreso económico alguno ni percibiera ningún tipo de ayuda social, siendo demandante de empleo y con cuatro hijos menores a su cargo, uno de ellos con una discapacidad reconocida (F.J.2). Igualmente, en la SAP de Madrid 160/2020, de 25 mayo, se apreció estado de necesidad y se estimó el recurso, declarando que la denunciada había acreditado una situación de precariedad económica tal, a la fecha de los hechos, que la colocaba en extrema vulnerabilidad a ella y a sus cuatro hijos menores. También quedó probado que acudió a los servicios sociales, negándole que pudiera acudir a prestaciones sociales no contributivas y a soluciones habitacionales de carácter social (F.J.2). Por otra parte, en la SAP de Murcia 402/2019, de 5 de diciembre, se revocó la sentencia y se absolvió a la recurrente, al quedar demostrado que se trataba de una madre soltera de un menor de siete años de edad y otro niño de escasos meses, que no tenía ingresos de ningún tipo y cuya única manera de «sobrevivir» y tener un techo era la ocupación del inmueble (F.J.2). Sin embargo, en este asunto no se precisa si la demandada se puso en contacto o no con los servicios sociales. También en la SAP de 
De hecho, en las resoluciones que recogen esas condiciones se ponen de manifiesto las graves dificultades económicas que padecen muchas de las personas que se instalan en inmuebles ajenos ${ }^{111}$. Pero señalan que compete al legislador acometer reformas urgentes, habilitando los medios para afrontar las situaciones de penuria y a los servicios sociales tratar de resolverlas ${ }^{112}$.

En cierta forma, esta jurisprudencia contrasta con algunas medidas de política social adoptadas recientemente por la administración. En particular, con la aprobada por el Consejo de Ministros, de suspender los desahucios en supuestos de vulnerabilidad motivados por el Covid, reconociendo la existencia de un grupo creciente de ciudadanos que no puede hacer frente al alquiler debido a los problemas laborales ocasionados por la pandemia ${ }^{113}$. Lo mismo sucede con algunas iniciativas autonómicas, como la de Cataluña, donde se da el mayor número de estos delitos y que ha previsto legalmente la posibilidad de obligar a las entidades bancarias y a los fondos de inversión a ofrecer a unos precios accesibles algunos de sus pisos vacíos ${ }^{114}$. Es cierto que estas soluciones no se pueden trasladar al orden penal, puesto que el delito del artículo 245.2 CP se caracteriza porque no hay una ocupación lícita previa. Pero sí pone de relieve una realidad social acuciante que debería orientar al legislador, más a la despenalización de este ilícito que al incremento de su penalidad ${ }^{115}$, como se propone en las últimas Proposiciones de Ley.

Valencia 274/2020, de 23 de julio, se aplica la eximente de estado de necesidad puesto que hay un informe social de vulnerabilidad emitido por el Ayuntamiento de Valencia donde se acredita que la recurrente se encuentra en posición económica precaria y en situación laboral de desempleo, siendo además familia monoparental con una hija enferma que precisaba cuidados especiales (F.J.3).

111 De todos modos, las circunstancias personales del delincuente sí se tendrán en cuenta en la determinación de la pena. Como señala CÁMARA ARROYO, esas circunstancias, a diferencia de la gravedad del hecho delictivo, son factores de determinación de la pena, que funcionan como índices que aconsejan rebajar la pena proporcionada y llevarla al mínimo legal previsto sin ser atenuantes de la responsabilidad penal. CÁmARA ARROYO, S., "Justicia Social y Derecho penal: individualización de la sanción penal por circunstancias socioeconómicas del penado (arts. 66.1.6, 20.7 CP y 7.3 LORRPM)", en ADPCP, Vol. LXVIII, 2015, pp. 246 y 247.

112 SAP de Madrid 809/2019, de 30 de noviembre (F.J.3), y, AAP de Barcelona 269/2020, de 11 de mayo (F.J.6).

113 Real Decreto-ley 11/2020, de 31 de marzo, por el que se adoptan medidas urgentes complementarias en el ámbito social y económico para hacer frente al Covid-19 (https:// www.boe.es/buscar/act.php?id=BOE-A-2020-4208); y, Real Decreto-ley 30/2020, de 29 de septiembre, de medidas sociales en defensa del empleo (https://www.boe.es/diario_boe/txt. php?id=BOE-A-2020-11416).

${ }_{114}$ Ley 24/2015, de 29 de julio, de medidas urgentes para afrontar la emergencia en el ámbito de la vivienda y la pobreza energética (https://www.boe.es/buscar/act.php?id=BOEA-2015-9725).

115 De otra opinión, Jiménez PaRís, J.M.: La ocupación de inmuebles en el Código penal español, Reus, Madrid, 2018, p. 15. También Сово DEL Rosal criticaba la jurisprudencia renuente a aplicar esta figura delictiva, atendiendo al sector doctrinal que aboga por su despenalización. Cobo Del Rosal, M.: "La nueva concepción del delito de usurpación", 


\subsubsection{La interpretación restrictiva de los elementos típicos}

El primer elemento que suscita discrepancias en la práctica forense es la delimitación del bien jurídico protegido en el artículo 245.2 CP y, en particular, la concreción del perjuicio necesario para realizar el delito.

En la citada STS 800/2014, de 12 de noviembre, el tribunal declaró que "el bien jurídico protegido es el patrimonio inmobiliario, y como delitos patrimoniales la lesión del bien jurídico requiere que se ocasione un perjuicio al titular del patrimonio afectado, que es el sujeto pasivo del delito"116.

Pues bien, no se cuestiona que lo que se tutela no es el derecho de posesión, que puede y debe discutirse en sede civil, sino la posesión material, o señorío sobre el bien, para que el titular pueda darle el uso que considere $^{117}$. Desde esta óptica, se excluye la ocupación de inmuebles en estado de abandono o ruinoso, aunque no basta que no tengan los suministros básicos de agua y electricidad, sino que han de estar en un estado de deterioro tal que impida habitarlos en condiciones dignas ${ }^{118}$. Igualmente, se consideran atípicos los casos en que la posesión se adquirió del titular inicialmente de un modo lícito, bien mediante un contrato o en precario ${ }^{119}$.

Más controversia genera la exigencia de que la ocupación cree un "riesgo relevante para la posesión", que según el Tribunal Supremo es lo que dota de lesividad y significación típica a la conducta, excluyendo expresamente las ocupaciones ocasionales o esporádicas, sin vocación de permanencia o de escasa intensidad.

Pues bien, a partir de este presupuesto, algunos órganos judiciales requieren que la estancia se prolongue durante un tiempo ${ }^{120}$, considerándolo

en Lawyerpress News, 18 de febrero de 2014 (https://www.lawyerpress.com/news/2014_02/ delito_de_usurpación.html).

116 STS 800/2014, de 12 de noviembre (F.J.3).

117 SAP de Las Palmas 181/2000, de 13 de octubre (F.J.1), SAP de Valencia 130/2001, de 9 de mayo (F.J.2), SAP de Tenerife 274/2019, de 2 de septiembre (F.J.3), SAP de Barcelona 139/2020, de 24 de febrero (F.J.3), y, AAP de Barcelona 269/2020, de 11 de mayo (F.J.9).

118 SAP de Les Illes Balears 127/2019, de 19 de diciembre (F.J.2), y, SAP de Las Palmas 131/2020, de 21 de mayo (F.J.2).

119 Esta exclusión se mantiene en la práctica judicial, como expone la SAP de Tenerife 383/2019, de 15 de noviembre (F.J.1). Pueden consultarse, también, la SAP de Barcelona 191/2020, de 9 de junio (F.J.3), y, la SAP de Barcelona 523/2019, de 2 de septiembre (F.J.3).

120 SAP de Burgos de 17 de enero de 2000 (F.J.2), SAP de Madrid 103/2020, de 5 de marzo (F.J.3), SAP de Madrid 115/2020, de 12 de marzo (F.J.2), SAP de Barcelona 184/2020, de 17 de abril (F.J.3), y, SAP de Lleida 145/2020, de 9 de julio (F.J.2). Puede consultarse más jurisprudencia al respecto en, Rodríguez Ramos, L. (dir.), Código penal (concordado y comentado con jurisprudencia) y leyes penales especiales y complementarias, La Ley, Madrid, 2015, pp. 1254 y ss; y, Rubio PéRez De Acevedo, M.P., "La usurpación de inmuebles. Estudio del artículo 245.2 del Código Penal", en Revista Jurídica de la Comunidad de Madrid, no 29, 30 de diciembre de 2009 (http://www.madrid.org/revistajuridica/). 
un delito permanente ${ }^{121}$. Desde este prisma, aprecian tentativa si los ocupantes están un lapso breve, pero queda acreditada su vocación de permanencia $^{122}$. En cambio, otros lo declaran consumado con la entrada ilegal, si se constata esa intención ${ }^{123}$. En mi opinión, para que haya "ocupación"124 es necesario que la estancia en el inmueble tenga cierta duración, de manera que estos supuestos serían formas imperfectas de ejecución. Así lo requiere el principio de proporcionalidad, que cita el propio tribunal como elemento de juicio para afirmar la lesividad y también el tenor de la ley, pues a diferencia del allanamiento de morada el artículo $245.2 \mathrm{CP}$ no habla meramente de entrar, sino de ocupar, que implica algo más, en

121 SAP de Madrid 36/2020, de 27 de febrero (F.J.3), SAP de Barcelona 186/2020, de 11 de marzo (F.J.1), AAP de Barcelona 215/2020, de 30 de marzo (F.J.3), SAP de Barcelona 217/2020, de 30 de marzo (F.J.2), SAP de Barcelona 184/2020, de 17 de abril (F.J.3), SAP de Madrid 139/2020, de 25 de mayo (F.J.5), SAP de Madrid 168/2020, de 25 de mayo (F.J.3), SAP de Barcelona 191/2020, de 9 de junio (F.J.3), y, SAP de Madrid 234/2020, de 23 de junio (F.J.3).

${ }_{122}$ La SAP de Barcelona 623/2019, de 2 de octubre, confirma la condena en grado de tentativa porque, aunque la ocupación no se extendió por la intervención de los vecinos, quienes avisaron a la policía tras detectar la presencia de la acusada y la de otros dos jóvenes sin identificar, estos habían cambiado la cerradura, hecho que revela la intención de residir allí durante un tiempo relevante (F.J.4). El AAP de Barcelona 806/2019, de 8 de octubre, estima el recurso contra el Auto de archivo de la causa abierta contra dos personas que estaban intentando forzar la puerta de una vivienda, manifestando a los agentes al ser sorprendidas, que querían ocupar el inmueble. El Auto se basa en que la propia Audiencia en alguna resolución reciente había apreciado el delito del artículo 245.2 CP en grado de tentativa (F.J.1). La SAP de Valladolid 103/2020, de 3 de julio, revocó la sentencia que aplicó el delito consumado y lo declaró en grado de tentativa. Los acusados entraron en la vivienda y la desalojaron poco después a requerimiento de la policía, a la que avisaron los vecinos. Manifestaron que su intención era cambiar la cerradura a fin de vivir en ella sin que les pudieran echar, pretendiendo así una desposesión del inmueble para su titular de forma continuada y estable en el tiempo (F.J.2). La SAP de Madrid 177/2020, de 3 de junio, confirmó el delito del artículo 245.2 CP en grado de tentativa (F.J.1), y, también la SAP de la Coruña 282/2020, de 7 de julio (F.J.1). Por su parte, la SAP de Les Illes Balears $127 / 2020$, de 21 de abril, ratificó la condena por un delito leve consumado del artículo 245.2 CP, desestimando la pretensión del recurrente de apreciarlo en grado de tentativa, porque del relato de hechos probados no se deduce, en modo alguno, que la intervención policial fuera inmediata a la entrada de los denunciados en la finca ni que impidiera la consumación del delito (F.J.5).

123 "El ocupar se consuma con la mera introducción del sujeto activo en el inmueble, sin autorización, siempre que haya voluntad de permanencia”. SAP de Granada 152/2020, de 8 de mayo (F.J.2). Así pues, en la SAP de Madrid 756/2019, de 30 de diciembre, se sostiene que "la denunciada, en compañía de otras personas accedieron al interior de la vivienda, permaneciendo en ella, según la vecina que avisa a los policías, "la denunciada debió estar de una noche para otra o medio día». Por tanto, el delito cometido lo fue en grado de consumación" (F.J.2). En la SAP de Valencia 235/2020, de 29 de junio, se declara que "el delito leve se consumó por el hecho de que la pareja entrara, sin autorización alguna, a la vivienda, una vivienda desocupada, cuyas puertas forzaron y donde llegaron a instalar un colchón”, aunque las precauciones de la propiedad, que revisaba día a día que la vivienda fuere respetada, hayan impedido una permanencia prolongada en el tiempo (F.J.1).

124 Según del Diccionario de la RAE, "ocupar" significa: 1. tr. Tomar posesión o apoderarse de un territorio, de un lugar, de un edificio, etc., invadiéndolo o instalándose en él”. 
el sentido de apoderarse, instalarse, durante un tiempo con voluntad de continuidad $^{125}$.

Por otra parte, la ubicación del artículo 245.2 CP en el Título XIII determina que la posesión amparada penalmente es la derivada de la propiedad, quedando excluida la vinculada a otros derechos ${ }^{126}$. Así se desprende también de la literalidad del precepto que habla del "titular" del inmueble, vivienda o edificio ${ }^{127}$. No obstante, algunos tribunales han afirmado que puede ser sujeto pasivo tanto el propietario como la persona que tenga derecho a ocupar esos bienes ${ }^{128}$. Lo cierto es que, al no tratarse de morada, en la práctica quienes tienen pisos o locales desocupados son los propietarios. De todos modos, si, por ejemplo, la vivienda deshabitada estuviera arrendada y fuera ocupada ilegalmente, se vería igualmente afectada la facultad de uso del propietario y será esta potestad la que pueda reclamarse en el proceso penal ${ }^{129}$. Esta interpretación se deduce, también, de la STS 800/2014, de 12 de noviembre.

Así pues, acreditándose la ocupación de un inmueble que reúne las condiciones mínimas de habitabilidad, con vocación de permanencia y sin el consentimiento del propietario, se podrá afirmar la antijuridicidad material de la conducta.

Pero en los últimos años diversos órganos judiciales han tomado partido ante la problemática económica que subyace a esta infracción y establecen que la respuesta debe ser distinta en función del sujeto pasivo, pese a no recogerse esta diferencia en el artículo $245.2 \mathrm{CP}$. Aducen que la lesión al bien jurídico reviste más relevancia y se considera socialmente más digna de reproche (teoría de la adecuación social), cuando la ocupación afecta a un particular que si perjudica a una institución bancaria o de inversión que, por lógica, tienen en cartera esos inmuebles para su explotación ${ }^{130}$.

125 Además, alega MAgro Servet que el hecho de que el legislador haya distinguido entre las dos modalidades comisivas es suficientemente significativo de que la primera requiere de una duración temporal de suficiente entidad. Magro SERVET, "Ocupación ilegal de inmuebles...", cit., p. 3.

126 SAP de Cádiz 412/2000, de 6 de octubre (F.J.1), SAP de Las Palmas 181/2000, de 13 de octubre (F.J.2), y, SAP de Barcelona 128/2020, de 24 de febrero (F.J.6).

127 De esta opinión, Manzanares Samaniego, Comentarios al Código penal..., cit., p. 882; Queralt Jiménez, J.J., Derecho penal español. Parte especial, cit., p. 445, y, RomeO Casabona, C.M./Sola Reche, E./Boldova Pasamar, M.A., Derecho Penal. Parte especial, cit., p.356.

128 SAP de Valencia 130/2001, de 9 de mayo (F.J.2), SAP de Córdoba 235/2011, de 23 de septiembre (F.J.3), y, SAP de Murcia 236/2020, de 10 de septiembre (F.J.1).

129 Incluyen a los usufructuarios, FERnÁndez APARICIO, J.M.: "Comentario al artículo 245 párrafo $2^{\text {o”, }}$ cit., p. 2; y, HERNÁNDEZ GARCÍA, "La protección constitucional de la vivienda...", cit., p. 22.

130 SAP de Les Illes Balears 127/2019, de 19 de diciembre (F.J.2), y, SAP de Mallorca 266/2020, de 16 de septiembre (F.J.1). Crítica la desprotección de las personas jurídicas, RodRíguez LaIN, J.L., “Discrepancias y refutaciones a la Instrucción de la Fiscalía General 
Desde este prisma, añaden un requisito adicional al relativo a la conservación y mantenimiento del bien y precisan su uso o disposición efectivos ${ }^{131}$.

En efecto, para colmar el delito es indispensable que la posesión sea socialmente manifiesta, condición que se niega cuando la vivienda o local están en un estado de abandono o deterioro ${ }^{132}$. Pero especialmente cuando pertenece a un banco o a una sociedad inversora algunos tribunales niegan el delito si esos propietarios se han despreocupado durante un largo periodo de tiempo ${ }^{133}$ y no han ejercido ningún control posesorio sobre el inmueble ${ }^{134}$. De manera que deben demostrar cierta vocación de uso desde su adquisición, al menos poniéndolo en el mercado para su venta o alquiler. En definitiva, han de acreditar actos materiales que impliquen un interés en su utilización que supere el puro beneficio económico de la inversión inmobiliaria. De lo contrario, dicen esos tribunales, el proceso

del Estado 1/2020 sobre medidas cautelares de desalojo de inmuebles ocupados ilegalmente", en Diario La Ley, no 9709, Sección Doctrina, 5 de octubre de 2020, p. 11.

131 En la doctrina, considera que la posesión solo se debe tutelar cuando hay una utilización material efectiva, o en aquellos casos en que la actuación del sujeto pasivo revela su voluntad de ofrecer un uso inmediato o inminente al objeto del delito, atendiendo al principio de fragmentariedad del Derecho penal, CASAS VILLA, "Reflexiones en torno al delito de usurpación...", cit., pp. 7 y 8.

132 "La determinación de la existencia de una relación posesoria o de señorío sobre una cosa se debe hacer sobre la base de la conciencia social que exista sobre dicha relación; habrá posesión, en consecuencia, en la medida en que la conciencia común en un determinado ámbito social entienda que ésta existe sobre una cosa... Son los actos de voluntad sobre la cosa los que la hacen manifestarse socialmente. De esta forma..., teniendo en cuenta el carácter excepcional de la protección penal y atendiendo al criterio de proporcionalidad que debe informar toda intervención penal, sólo cabe considerar entre las situaciones amparadas por el artículo $245.2 \mathrm{CP}$, aquellas formas específicas de perturbación de la posesión de un inmueble, vivienda o edificio ajeno consistente en la ocupación o mantenimiento dentro de ellos que signifiquen un riesgo a una posesión que sea clara y socialmente manifiesta. Esta intervención penal aparece desproporcionada tratándose de fincas abandonadas, en mal estado; pero no es el criterio de la habitabilidad el que ha de considerarse para hacer entrar en juego la norma penal, sino el del bien jurídico que se trata de proteger con ésta que es, como se ha dicho, la posesión del propietario socialmente manifiesta". SAP de Las Palmas 181/2000, de 13 de octubre (F.J.2). En el caso enjuiciado, el acusado ocupó un apartamento adjudicado a una sociedad, que no lo llegó a ocupar, estando la propiedad en litigio. Dice el tribunal que el estado de abandono del apartamento durante un largo período de tiempo denota que no existía una posesión socialmente manifiesta acreditada por el propietario, toda vez que se trataba de un inmueble sin habitar, en estado lamentable, al que entró el acusado de forma pacífica para utilizarlo como vivienda. Una intervención penal, en este caso, sería contraria a la exigencia de proporcionalidad que se deriva del principio de justicia recogido constitucionalmente en el artículo 1.1 CE. (F.J.3). Requieren, también, que la posesión sea manifiesta, la SAP de Cádiz 412/2000, de 6 de octubre (F.J.1), SAP de Valencia 130/2001, de 9 de mayo (F.J.5), SAP de Huelva 17/2004, de 5 de febrero (F.J.4), SAP de Córdoba 235/2011, de 23 de septiembre (F.J.3), y, SAP de Burgos 60/2014, de 17 de febrero (F.J.2).

133 SAP de Barcelona 224/2020, de 7 de abril (F.J.2).

134 SAP de Les Illes Balears 127/2019, de 19 de diciembre (F.J.2). No obstante, la SAP de Madrid 186/2020, de 11 de marzo, afirma con carácter general esta exigencia (F.J.2). 
penal se convertiría en un mero expediente administrativo para recuperar el bien, sin la necesaria prueba de cargo de los elementos del delito ${ }^{135}$, en concreto, la existencia de un perjuicio real a la facultad de disfrute ${ }^{136}$. En

135 AAP de Barcelona 269/2020, de 11 de mayo (F.J.5), y, SAP de Las Palmas 131/2020, de 21 de mayo (F.J.3). Critica la exigencia de que los pisos de las entidades bancarias no estén vacíos para aplicar el art. 245.2 CP, MAGRo SERVET, V., "El delito de ocupación de inmuebles del art. 245.2. ¿Vía penal o vía civil?”, en La Ley Penal, $\mathrm{n}^{\circ}$ 126, mayo-junio 2017, p. 5.

136 "Perturbaciones transitorias o que recaigan sobre cosas o inmuebles sobre las que su titular no ejercite efectiva y actualmente los derechos de disfrute que se derivan del derecho a poseer no merecen ser penalmente castigadas. El Código penal no puede estar al servicio de exclusivos intereses recuperatorios de la posesión material de la cosa cuando el poseedor civil se ha despreocupado durante un largo periodo de tiempo del ejercicio de su derecho, sin perjuicio, obviamente, de las facultades de exclusión y de recuperación posesoria que le ofrecen el Código civil y las leyes procesales". SAP de Barcelona 767/2019, de 22 de noviembre (F.J.4), y, SAP de Barcelona 224/2020, de 7 de abril (F.J.2). "La denunciante acredita la propiedad del bien inmueble en cuestión y la ocupación por parte de la denunciada, pero nada más, ya que no cabe apreciar que tal posesión conlleve un riesgo relevante para la posesión del sujeto pasivo sobre el inmueble afectado..., pues de lo actuado aunque se desprende un tiempo considerable de permanencia, (unos tres años)..., no se acredita que se haya lesionado de forma inmediata, directa y grave el derecho a poseer, resaltando que frente a la conducta denunciada existen contundentes y eficaces mecanismos de protección civil que la propiedad puede sin duda utilizar. No existe por tanto prueba de cargo que ayude a identificar una conducta penalmente relevante, más allá de la mera molestia e incomodidad que la acreditada ocupación pudiera causar de manera eventual a la entidad propietaria”. SAP de Las Palmas 18/2020, de 24 de enero (F.J.3). "De acuerdo con lo expuesto, en este caso habrá que analizar las pruebas aportadas para acreditar si el denunciante ha ejercido la posesión sobre el inmueble pues estaría incluido, en este tipo delictivo el ataque a la posesión fáctica pero no al derecho a poseer, conforme a la doctrina civilista que distingue entre el ius possessionis y el ius possidendi. En el primer caso, se advierte un cambio en la situación de hecho, cuyo reproche y sanción se incluye en la norma penal..., mientras que en el segundo caso existirá un litigio puramente civil para definir quién sea el titular del derecho a poseer". SAP de Toledo 72/2019, de 28 de noviembre (F.J.2), y, SAP de Toledo 74/2019, de 2 de diciembre (F.J.2). "La ocupación penalmente relevante debe equivaler en su resultado antijurídico no sólo a un acceso a la posesión, como describe el artículo 438 CC, sino a una exclusión del legítimo titular del ius possesionis a su actual disfrute pacífico y a las utilidades que constituyen una consecuencia derivada del mismo. Perturbaciones transitorias o que recaigan sobre cosas o inmuebles sobre las que su titular no ejercite efectiva y actualmente los derechos de disfrute que se derivan del derecho a poseer no merecen ser penalmente castigadas". SAP de Barcelona 623/2019, de 2 de octubre (F.J.3). “Todas las cuestiones sobre el fondo de la cuestión, es decir, sobre la concurrencia de los elementos objetivos y subjetivos del tipo, han de plantearse en la fase de enjuiciamiento... En concreto, si la entidad denunciante ha llevado a cabo, previamente al hecho denunciado, una actividad de ejercicio del derecho posesorio ligado a la propiedad cuya alteración justifique el uso del Derecho penal". AAP de Barcelona 269/2020, de 11 de mayo (F.J.5). También la SAP de Barcelona $523 / 2019$, de 2 de septiembre, señala que, "no consta que, desde la fecha de adquisición, la misma haya estado arrendada o haya sido utilizada con algún acto de posesión efectiva por parte del titular" (F.J.2). Y, la SAP de Barcelona 224/2020, de 7 de abril, alega que, "no se ha justificado, que la entidad apelante venga realizando un ejercicio efectivo de la titularidad dominical que ostenta que justifique la aplicación preferente de la vía penal sobre las vías interdictales de recuperación de la posesión” (F.J.3). 
consecuencia, consideran que esas ocupaciones no deben ser objeto de sanción penal en virtud del principio de intervención mínima, pudiendo acudir el titular a la jurisdicción civil para recobrar la posesión ${ }^{137}$.

Además, mientras tradicionalmente se ha entendido que no es necesario un requerimiento formal de abandono por parte del propietario ${ }^{138}$, sino que basta la denuncia o querella ${ }^{139}$, cuando la vivienda pertenece a esas entidades, algunas resoluciones precisan que haya existido ese exhorto previo ${ }^{140}$.

\subsubsection{Consideraciones personales}

A mi modo de ver, la interpretación restrictiva que han realizado diversos órganos judiciales en los últimos años ante la necesidad, según expresan, de acatar el principio de legalidad y de aplicar unos tipos que están vigentes, evidencia la conveniencia de despenalizar estas conductas y de articular normas civiles eficaces, en lugar de incrementar la penalidad en el sentido que apuntan las últimas Proposiciones de Ley. Por otro lado, no hay que olvidar que la ocupación en sí ya constituye una infracción administrativa, de modo que, además de dejar el inmueble el infractor tendría que pagar una multa.

En realidad, el esfuerzo de esos tribunales por limitar el campo de aplicación del artículo 245.2 CP les lleva a efectuar una lectura de los

137 SAP de Les Illes Balears 127/2019, de 19 de diciembre (F.J.2), y, AAP de Barcelona 269/2020, de 11 de mayo (F.J.5). De esta opinión, también, Gómez IBARguREN, P., "El fenómeno okupa desde la perspectiva del Derecho penal”, en Noticias Jurídicas, 1 de noviembre de 2007 (https://noticias.juridicas.com/conocimiento/articulos-doctrinales/4326el-fenomeno-okupa-desde-la-perspectiva-del-derecho-penal/).

138 En la práctica judicial se ha estimado que es irrelevante que el propietario desconozca lo sucedido o esté ausente, presumiéndose iuris tantum la falta de autorización o la voluntad contraria del dueño en viviendas, fincas y espacios no edificados cercados. Magro Servet, "El delito de ocupación de inmuebles...", cit., p. 6.

139 "El delito por el que ha sido condenado el acusado no exige un requerimiento formal del propietario de la finca”. SAP de Cáceres 48/2003, de 22 de julio (F.J.2). "No requiere el tipo ninguna notificación solemne, con o sin notario, por parte del titular dominical para integrar la oposición a la ocupación, como parece creer el recurrente. La denuncia, que es obvio que conocía el acusado, es más que suficiente medio de manifestar oposición. La mera denuncia es ya manifestación cualificada de expresa voluntad de oposición". SAP de Sevilla 409/2019, de 1 de octubre (F.J.1). En igual sentido, SAP de Les Illes Balears 127/2019, de 19 de diciembre (F.J.2), SAP de Madrid 676/2019, de 19 de diciembre (F.J.2), SAP de Granada 152/2020, de 8 de mayo (F.J.2), SAP de Madrid 127/2020, de 14 de mayo (F.J.4), SAP de Madrid 139/2020, de 25 de mayo (F.J.5), SAP de Madrid 197/2020, de 1 de junio (F.J.2), SAP de Madrid 199/2020, de 1 de junio (F.J.4), SAP de Madrid 216/2020, de 16 de junio (F.J.2), SAP de Madrid 234/2020, de 23 de junio (F.J.3), SAP de Madrid 266/2020, de 9 de julio (F.J.2), y, SAP de Madrid 302/2020, de 8 de septiembre (F.J.2).

140 SAP de Barcelona 523/2019, de 2 de septiembre (F.J.2), SAP de Barcelona 224/2020, de 7 de abril (F.J.3), y, SAP de Barcelona 306/2020, de 30 de junio (F.J.3). 
elementos del delito que a mi modesto entender es cuestionable desde el principio de legalidad.

Por una parte, exigir el uso efectivo del inmueble por el propietario, o la realización de actos que reflejen su intención de utilizarlo, creo que excede de la lesión al bien jurídico protegido que precisa el tipo. Si lo que se tutela es la posibilidad de poseerlo y disfrutarlo que corresponde al titular, es evidente que el hecho de la ocupación se lo impide mientras dure la situación ilícita, con independencia de que haya ejercido o no esa facultad en el pasado. De manera que, por deplorable que resulte la desigualdad social que estos escenarios reflejan, se ha de amparar esa disponibilidad del dueño sobre la posesión del bien, sin exigirle que demuestre el destino que le ha dado.

Por otra parte, en la citada disposición se precisa que la ocupación se haga sin la autorización debida, o el mantenimiento contra la voluntad del titular ${ }^{141}$. A mi juicio, esta segunda modalidad ${ }^{142}$ contempla los supuestos en que el autor permanece en el inmueble pese a la oposición expresa del propietario, a diferencia de la primera en que basta la ausencia de su consentimiento ${ }^{143}$.

Luego, el requerimiento de desalojo no es un elemento típico, porque si se da y se incumple se aplica esta segunda modalidad delictiva ${ }^{144}$. Pese

141 Precisa que si existe autorización inicial su posterior exclusión no da lugar al delito, Vázouez Iruzubieta, C., Código penal comentado, Atelier, Barcelona, 2015, p. 427.

142 RAMÓN RIVAS plantea tres interpretaciones. La primera supone entender que "mantenerse en ellos" se refiere a las conductas de permanencia en el inmueble tras ocupaciones lícitas iniciales que han dejado de legitimar la posesión. La segunda implica la existencia de una ocupación inicial ilegal, lo que plantea el problema, a juicio de este autor, de que el mantenimiento no sería una conducta independiente sino una prolongación de ella. La tercera, que él sostiene, comporta la existencia de una ocupación ilícita inicial, es decir, sin título habilitante o legitimador de la posesión, pero solo en sentido objetivo, es decir, el sujeto activo debe ocupar sin autorización debida el inmueble, pero desconociendo, cuando lo ocupa, que lo hace sin tal autorización, es decir, sin dolo, en la creencia de que sí existe un título posesorio inicial que autoriza su ocupación. Si la buena fe inicial desaparece por tener conocimiento el ocupante como consecuencia, por ejemplo, de un intento de lanzamiento judicial, de la inexistencia de autorización debida, de un título posesorio que legitima su ocupación, el mantenimiento del inmueble se producirá contra la voluntad de su titular en los exactos términos exigidos por el artículo 245.2 CP. RAMÓN RIVAS, "El delito de ocupación ilegal no violenta de viviendas", cit., pp. 425 y ss.

143 La STS 800/2014, de 12 de noviembre, requería "que conste la voluntad contraria a tolerar la ocupación por parte del titular del inmueble, bien antes de producirse, bien después, lo que especifica este artículo al contemplar el mantenimiento en el edificio "contra la voluntad de su titular", voluntad que deberá ser expresa” (F.J.3).

144 De esta forma se facilita la condena cuando el autor alega una causa legítima inicial que no acredita (por ejemplo, que arrendó el inmueble a un tercero que dijo ser propietario), quedando probada la oposición expresa posterior del titular al conocer la ocupación. Un ejemplo se advierte en la SAP de Murcia 236/2020, de 10 de septiembre: "Si bien, refiere Clemente que ellos convivían con el anterior inquilino que tenía suscrito el contrato de arrendamiento, pero, no obstante, no aporta prueba alguna que 
a ello en alguna sentencia absolutoria se aduce la falta de esa reclamación para evidenciar que la entidad propietaria no manifestó interés en aprovechar el bien y, por ende, no se vio perjudicada en su posesión. Pero se trata de una condición no contemplada en el precepto, añadida con el fin de no criminalizar una conducta que, a su parecer, debería afrontarse en el ámbito civil. De nuevo, esta creación judicial de elementos no recogidos en la norma penal contradice el principio de legalidad.

Lo mismo sucede con la discriminación que efectúa algún órgano judicial en cuanto al sujeto pasivo, restando lesividad a la conducta cuando el inmueble pertenece a un banco o a un grupo inversor. La lesión del bien jurídico protegido no varía respecto a las propiedades de particulares, con independencia de la mayor o menor repulsa social que genere cada caso y que el juzgador no puede anteponer al tenor de la ley.

lo acredite... En consecuencia, de la prueba practicada resulta plenamente acreditada la ocupación de la vivienda referida por parte de los denunciados sin autorización de la entidad propietaria, y que se han mantenido en la misma pese a haber sido denunciados... Lo que constituye el delito leve de usurpación por el que fueron justamente condenados" (F.J.1). Otro supuesto lo recoge la SAP de Madrid 437/2020, de 27 de julio: "3.- En nuestro caso el alegato del apelante se dirige a cuestionar el dolo típico desde una perspectiva bifronte, a saber, ignoraba la ilicitud de la posesión puesto que el inmueble le había sido cedido por un tercero y, en cualquier caso, desconocía la voluntad contraria del "verus dominus" a dicha ocupación. 3.1.- Por lo que a la primera..., lo cierto es que no ha resultado probado, en modo alguno, que la posesión le hubiera sido cedida al recurrente por un tercero.... Llama al respecto poderosamente la atención que el ahora recurrente no aporte documentación alguna para la acreditación de su alegato, o testifical que lo patentice. 3.2.- La segunda..., resulta del testimonio prestado por los agentes del Cuerpo Nacional de Policía en el plenario conforme al cual se personaron en la vivienda al tiempo que el denunciante por haberse activado la alarma de la misma, y el ahora recurrente estaba en su interior teniendo que abrir el inmueble con las llaves que portaba el propietario. Igualmente resulta tal conocimiento del propio desarrollo del proceso en el curso del cual el denunciado recibió la citación a juicio, y a través de ella se evidencia la no disposición del dueño a permitir la ocupación" (F.J.2). Asimismo, la SAP de Madrid 54/2019, de 22 de enero: "No se aportó por la acusada ningún título que justificara la ocupación de la vivienda de la que no era propietaria, sin que las posibles solicitudes o trámites o negociaciones que afirma el abogado recurrente haber realizado para formalizar un contrato social excluya la realidad de los hechos declarados probados..., pero sí que consta -por prueba testifical y documental-, que con independencia de que la acusada pudiera entablar conversaciones con la entidad propietaria de la vivienda en un determinado momento, en el año 2017, la propietaria decidió no permitir a la acusada continuar en la vivienda, y a pesar de ello la acusada permaneció en la vivienda y de hecho al parecer en la fecha del juicio oral continua ocupando la misma, consciente ya desde la denuncia origen del presente procedimiento que no está autorizada a ocupar la vivienda por la entidad propietaria de la misma. La acusada doña Carina reconoce la acción típica configuradora del delito de usurpación del artículo 245.2 CP, ya que no solamente se castiga la acción de "ocupar sin autorización debida un inmueble", sino también el de "mantenerse en el inmueble contra la voluntad de su titular"”' (F.J.1). 


\section{Proposiciones de Ley de reforma del artículo 245.2 CP}

\subsection{Propuestas iniciales despenalizadoras}

Como decía, en julio de este año se publicaban las últimas Proposiciones de Ley, presentadas por los Grupos Parlamentarios Popular y Ciudadanos, para reformar el artículo $245.2 \mathrm{CP}$, con el fin de endurecer la penalidad y de crear figuras agravadas.

Estas iniciativas contrastaban con las propuestas legislativas iniciales, que promovían la supresión de ese delito.

En efecto, en $1998^{145}$ el Grupo Parlamentario Federal de Izquierda Unida presentó una Proposición de Ley para dejar sin contenido el apartado 2 del artículo 245 CP. Como fundamento, aducía que la denominada «ocupación» es un fenómeno social nacido de la dificultad de acceso a la vivienda y que al estado no le corresponde punir esas conductas mediante políticas meramente represivas, sino desarrollar las condiciones sociales que permitan evitarlas. Por otro lado, señalaba que la legislación civil ofrece los mecanismos necesarios para proteger los derechos de propiedad y posesión, por lo que no debe regir el Derecho penal, de carácter restrictivo.

Igualmente, el Grupo Parlamentario Mixto planteó dos Proposiciones de Ley en los años $1998^{146}$ y $2000^{147}$ que propugnaban la supresión de dicha norma, basándose en el principio de intervención mínima. Los textos confrontaban el derecho a la propiedad privada, que se protege en el precepto y el derecho a una vivienda digna, convertido en una aspiración, a veces ilusoria, dado que los poderes públicos no han creado las condiciones necesarias para hacerlo efectivo. Por eso, castigar a quien ocupa pacíficamente una vivienda ajena que no constituye morada, no se ajusta al reproche que la sociedad dirige a estas acciones. Poco después, en el año 2001 formuló otra Proposición de Ley donde argumentaba que la ocupación no merece una respuesta jurídico-penal, pues se debe a condicionantes superiores, provocados por la situación social y económica en que se encuentra una parte muy importante de nuestra juventud ${ }^{148}$.

145 Boletín Oficial de las Cortes Generales. Congreso de los Diputados. VI Legislatura. Serie B. Proposiciones de Ley. 13 de febrero de 1998. Núm. 152-1 (https://www.congreso. es/public_oficiales/L6/CONG/BOCG/B/B_152-01.PDF).

146 Boletín Oficial de Las Cortes Generales. Congreso de los Diputados. VI Legislatura. Serie B. Proposiciones de Ley. 13 de febrero de 1998. Núm. 154-1 (https://www.congreso. es/public_oficiales/L6/CONG/BOCG/B/B_154-01.PDF).

147 Boletín Oficial de las Cortes Generales. Congreso de los Diputados. VII Legislatura. Serie B. Proposiciones de Ley. 9 de junio de 2000. Núm. 73-1 (https://www.congreso.es/ public_oficiales/L7/CONG/BOCG/B/B_073-01.PDF).

148 Boletín Oficial de las Cortes Generales. Congreso de los Diputados. VII Legislatura. Serie B. Proposiciones de Ley. 23 de noviembre de 2001. Núm. 174-1 (https://www.congreso.es/public_oficiales/L7/CONG/BOCG/B/B_174-01.PDF). 
Por lo tanto, en todas las propuestas se estimaba que, en un contexto de pobreza, de precariedad laboral y de insuficiencia de viviendas sociales castigar penalmente el uso pacífico de inmuebles deshabitados es desproporcionado.

\subsection{Proposiciones de Ley del Grupo Parlamentario Popular}

A diferencia de las Proposiciones de Ley iniciales, las formuladas en los últimos años van en dirección opuesta y abogan por endurecer el régimen jurídico de este delito.

En el año 2019 el Grupo Parlamentario Popular presentó dos Proposiciones de $\mathrm{Ley}^{149}$, que incluían la reforma del artículo $245 \mathrm{CP}$, y su contenido se reproduce en la publicada el 17 de julio de $2020^{150}$.

Este texto lleva por título "Proposición de Ley Orgánica contra la ocupación ilegal y para la convivencia vecinal y la protección de la seguridad de las personas y cosas en las comunidades de propietarios". El enunciado refleja ya el cambio de enfoque en el tratamiento de esta figura.

Con carácter complementario se introducen algunas modificaciones importantes de carácter procesal, en los órdenes penal y civil.

En primer lugar, se reforma el artículo 795.2 LECrim, para que los delitos de usurpación del artículo 245 CP se tramiten por el juicio rápido. De esta forma se agiliza la instrucción y el enjuiciamiento de estas conductas.

En segundo lugar, se modifica el artículo 250.1.4 LEC, de modo que en el juicio verbal podrán solicitar la inmediata recuperación de la posesión de una vivienda ilícitamente ocupada, las personas físicas o jurídicas que sean propietarias o poseedoras legítimas por otro título. Por lo tanto, todas las personas jurídicas podrán pedir esta medida, incluyendo las privadas con ánimo de lucro, como los bancos u otras instituciones

149 “Proposición de Ley Orgánica contra la ocupación ilegal y para la convivencia vecinal y la protección de la seguridad de las personas y cosas en las comunidades de propietarios". Presentada por el Grupo Parlamentario Popular en el Congreso. Boletín Oficial de las Cortes Generales. Congreso de los Diputados. 8 de febrero de 2019. Núm. 369-1 (http://www.congreso.es/public_oficiales/L12/CONG/BOCG/B/BOCG-12-B-369-1.PDF), y, "Proposición de Ley Orgánica contra la ocupación ilegal y para la convivencia vecinal y la protección de la seguridad de las personas y cosas en las comunidades de propietarios”. Presentada por el Grupo Parlamentario Popular en el Congreso. Boletín Oficial de las Cortes Generales. Congreso de los Diputados. 11 de junio de 2019. Núm. 30-1 (http://www. congreso.es/public_oficiales/L13/CONG/BOCG/B/BOCG-13-B-30-1.PDF).

150 "Proposición de Ley Orgánica contra la ocupación ilegal y para la convivencia vecinal y la protección de la seguridad de las personas y cosas en las comunidades de propietarios". Presentada por el Grupo Parlamentario Popular en el Congreso. Boletín Oficial de las Cortes Generales. Congreso de los Diputados. 17 de julio de 2020. Núm. 96-1 (http:// www.congreso.es/public_oficiales/L14/CONG/BOCG/B/BOCG-14-B-96-1.PDF). 
inversoras, hasta ahora excluidas de este precepto. Por consiguiente, ninguna entidad ha de acudir a la jurisdicción penal para lograr esta pronta restitución. Esta previsión, sin duda, es positiva.

En el ámbito punitivo, la Proposición basa la nueva regulación en la existencia de "un bien jurídico a proteger que hasta ahora no ha tenido la debida consideración: la convivencia vecinal pacífica y respetuosa en aras de la seguridad de las personas y las cosas".

Bajo esta perspectiva novedosa se endurece la pena de las conductas previstas en el artículo $245 \mathrm{CP}^{151}$, sustituyendo en el apartado 2 la multa actual, por prisión de seis a dieciocho meses. Se crea un tipo agravado para los supuestos en que esta ocupación dure más de quince días y otro atenuado si la devolución se produce en un plazo no superior a cuarenta y ocho horas. Asimismo, se incrementa la pena cuando la ocupación se realiza con violencia o intimidación, pasando a ser prisión de uno a tres años, en lugar de uno a dos. Se introducen tipos específicos para las conductas practicadas por miembros de grupos organizados y para quienes promueven la ocupación ilegal, aumentando el castigo si quien la favorece es autoridad o funcionario.

Así pues, la mirada se pone en las molestias que en algunos supuestos sufren quienes residen cerca de los ocupantes, más que en el mismo

151 Artículo 245: “1. Al que con violencia o intimidación en las personas ocupare una cosa inmueble o usurpare un derecho real inmobiliario de pertenencia ajena, se le impondrá, además de las penas en que incurriere por las violencias ejercidas, la pena de prisión de uno a tres años, que se fijará teniendo en cuenta la utilidad obtenida y el daño causado.

2. El que ocupare, sin autorización debida, un inmueble, vivienda o edificio ajenos que no constituyan morada, o se mantuviere en ellos contra la voluntad de su titular, será castigado con la pena de prisión de seis a dieciocho meses.

3. Se impondrán las penas superiores en grado si la ocupación ilegal hubiera durado más de 15 días.

4. En los casos previstos en el párrafo segundo de este artículo, se impondrá la pena de trabajos en beneficio de la comunidad de treinta y uno a noventa días o multa de dos a doce meses, si el ocupante restituyera de forma plena, directa o indirectamente, en un plazo no superior a cuarenta y ocho horas, el inmueble ocupado a su legítimo propietario o poseedor.

5. En los casos contemplados en los números uno y dos de este artículo, se impondrán respectivamente las penas señaladas en el artículo 570 bis en la extensión en que se determine en función de la utilidad obtenida, de la duración de la ocupación y del daño causado, cuando la ocupación se realice por un grupo organizado. Se impondrán las mismas penas a los ocupantes que siguieran instrucciones de los miembros del grupo con conocimiento de la ilegalidad de la ocupación.

6. El que, sin participar en los hechos recogidos en este artículo, promoviera la ocupación sin justo título de una cosa inmueble ajena o la usurpación de un derecho real inmobiliario, a través de la elaboración o distribución de instrucciones o recomendaciones para la ocupación, o señalare inmuebles para ser ocupados ilegalmente, será castigado como autor de incitación a la ocupación a la pena de prisión de tres meses a un año.

7. Cuando los hechos descritos en el párrafo anterior fueran cometidos por autoridad o funcionario público en el ejercicio de su competencia, serán castigados con la pena de prisión de tres meses a un año y de inhabilitación especial para empleo o cargo público y para el ejercicio del derecho de sufragio pasivo por tiempo de nueve a quince años”. 
propietario del inmueble. Pero es patente que un valor tan etéreo no puede fundar el incremento penológico.

A mi modo de ver, el bien jurídico protegido en el artículo 245.2 $\mathrm{CP}$ es la disponibilidad del uso del inmueble, como facultad aneja a la propiedad ${ }^{152}$ y esta potestad en nada se ve afectada por esos eventuales conflictos de convivencia ${ }^{153}$. Por otra parte, no puede considerarse un delito pluriofensivo, en tanto el tipo no requiere ni la lesión ni la puesta en peligro de la seguridad colectiva ni del orden público. De hecho, estas contingencias ni se dan siempre, ni se concretan en actos específicos, de manera que no podrían colmar siquiera un delito de peligro abstracto. No cabe afirmar que toda ocupación conlleva este riesgo grave para la convivencia, como fundamento para anticipar la intervención penal.

Por lo tanto, se quiere endurecer la sanción de un ilícito que debería despenalizarse, basándose en circunstancias particulares que han de solventarse mediante la aplicación de los pertinentes delitos o infracciones administrativas, en caso de producirse efectivamente comportamientos ilícitos por parte de los autores. Desde luego, la elevación de la multa a prisión no puede fundarse en el malestar social que crean algunas ocupaciones ilegítimas, pues no hay que olvidar que una parte importante la protagonizan personas llevadas por su pobreza extrema.

Por otra parte, se dice que el aumento de estas acciones ha provocado una notable preocupación social, pero esta inquietud no supone un mayor reproche, máxime cuando en muchos casos las realizan sujetos en situación de miseria, o quienes buscan evidenciar el contraste entre estos dramas y la posición privilegiada de bancos y empresas que acumulan viviendas en su activo sin darles ningún destino. Me parece que la demanda social va por otros derroteros y lo que quiere es, por una parte, que se agilicen los procedimientos de lanzamiento, y, por otra, una mejor política social ${ }^{154}$, que proporcione alojamiento a los ciudadanos que carecen de recursos, e incluso que obligue a los bancos a ofrecerlas a precios asequibles cuando no las utilicen.

152 Coincido con la opinión mayoritaria. Véase, MANZANAREs SAMANIEGo, Comentarios al Código penal..., cit., p. 246.

153 Como señalaba HuERTA Tocildo, la ocupación consiste en una mera perturbación en el uso o disfrute del bien inmueble, sin ánimo de apropiación, a diferencia de la usurpación, que tipifica ahora el artículo 245.1 CP y que sí conlleva la atribución de la titularidad de un derecho real. Huerta Tocildo, S., Protección penal del patrimonio inmobiliario, Civitas, Madrid, 1980, p. 80.

154 Como dice SERrano TÁrRaga, "la pobreza es una de las causas de la criminalidad íntimamente ligada a las políticas sociales. El fracaso de las mismas lleva a la pobreza y ésta a la delincuencia”. SERrANo TÁRrAGA, M.D., "Exclusión social y criminalidad”, en Revista de Derecho de la UNED, n 14, 2014, p. 590. 


\subsection{Proposiciones de Ley del Grupo Parlamentario Ciudadanos}

El Grupo Parlamentario Ciudadanos también ha presentado varias Proposiciones de Ley, en las que incluye una nueva redacción del artículo $245 \mathrm{CP}^{155}$, con igual contenido. La anterior en el año $2018^{156}$ y la última publicada el 17 de julio de $2020^{157}$, bajo la rúbrica "Proposición de Ley de garantías para la seguridad y convivencia ciudadanas frente a la ocupación ilegal de viviendas".

En la Exposición de Motivos distingue dos tipos de ocupaciones ilegales. "Por un lado, las llevadas a cabo por individuos o grupos de delincuencia organizada (a veces incluso por grupos terroristas), que las perpetran de forma premeditada y con una finalidad lucrativa, aprovechándose de las personas en situación de vulnerabilidad a las que tenemos a bien proteger, a veces incluso extorsionándolas para obtener

155 Artículo 245 CP: “1. Al que con violencia o intimidación en las personas ocupare una cosa inmueble o usurpare un derecho real inmobiliario de pertenencia ajena, se le impondrá, además de las penas en que incurriere por las violencias ejercidas, la pena de prisión de uno a dos años, que se fijará teniendo en cuenta la utilidad obtenida y el daño causado.

2. El que con fuerza en las cosas ocupare un inmueble, vivienda o edificio ajenos, que no constituyan morada habitual, será castigado, además de con las penas en que incurriere por las violencias ejercidas, con la pena de prisión de uno a dos años.

3. El que ocupare, sin justo título, un inmueble, vivienda o edificio ajenos que no constituyan morada habitual, o se mantuviere en ellos contra la voluntad de su titular, será castigado con la pena de multa de seis a doce meses.

Cuando el que cometiere el delito lo hiciere con la finalidad de utilizar el inmueble, vivienda o local para el desarrollo de otras actividades delictivas, se le impondrá la pena de prisión de seis meses a un año y multa de seis a doce meses, sin perjuicio de las penas en que pudiere incurrir por los delitos conexos a la ocupación del inmueble.

4. Al que, con lucro o con ánimo del mismo, mediare o interviniere para que otra persona ocupare, sin justo título, un inmueble, vivienda o local ajenos, que no constituyan morada habitual, o para que se mantuviere en ellos contra la voluntad de su titular, se le impondrá la pena de prisión de uno a dos años y multa de seis meses a un año, sin perjuicio de las penas en que pudiere incurrir por las violencias que en su caso hubiere ejercido con tal finalidad.

Cuando el que cometiere el delito formare parte de un grupo u organización criminal, será castigado, además de con las penas en que incurriere por dicha pertenencia, con la pena de prisión de dos a cuatro años y multa de seis meses a dos años, o del tanto al duplo del beneficio obtenido o que se hubiere podido obtener si la cantidad resultante fuese más elevada”.

156 "Proposición de Ley de garantía de la seguridad y convivencia ciudadanas frente a la ocupación ilegal de viviendas". Presentada por el Grupo Parlamentario Ciudadanos. Boletín Oficial de las Cortes Generales. Congreso de los Diputados. 6 de abril de 2018. Núm. 242-1 (http://www.congreso.es/public_oficiales/L12/CONG/BOCG/B/BOCG12-B-242-1.PDF).

157 "Proposición de Ley de garantías para la seguridad y convivencia ciudadanas frente a la ocupación ilegal de viviendas”. Presentada por el Grupo Parlamentario Ciudadanos. Boletín Oficial de las Cortes Generales. Congreso de los Diputados. 17 de julio de 2020. Núm. 7-1 (http://www.congreso.es/public_oficiales/L14/CONG/BOCG/B/BOCG-14-B-97-1.PDF). 
una compensación económica como condición previa para recuperar su vivienda; y, por otro, las realizadas por grupos antisistema”.

Pero el texto no menciona, junto a los dos colectivos señalados, a esas personas vulnerables, que además de víctimas pueden ser autoras. $\mathrm{Y}$, como se verá, en caso de cometer una ocupación pacífica de vivienda quedarán sujetas a una pena mayor a la actual, puesto que se incrementa la sanción de esta conducta.

A continuación, la propia Exposición de Motivos añade que la «okupación» es un acto ilegal que tiene como víctimas no solo a los dueños, sino también a los vecinos, al sufrir el deterioro de la convivencia, mencionando el caso extremo del tráfico de drogas. Por lo tanto, también se pone el acento en la paz vecinal, aunque sin atribuirle la condición de bien jurídico protegido. Por su parte, sigue diciendo, los propietarios e inquilinos se encuentran ante la imposibilidad de entrar en su propia casa al volver de unas vacaciones o de una corta ausencia. Por consiguiente, para justificar los cambios alude a un delito grave que rebasa la ocupación y conlleva penas elevadas y a ciertos hechos que tienen encaje en el delito de allanamiento de morada del artículo 202 CP.

Después argumenta que la ley responde a una perspectiva integral de la «okupación», porque "no se puede cerrar los ojos ante la evidencia de que, en algunos casos, los ocupantes sufren unas necesidades que deben ser atendidas".

Pero penalmente el reconocimiento de esta "evidencia" se concreta en un endurecimiento del castigo aplicable a esas personas que llevadas por su situación de pobreza se limiten a establecerse en un inmueble ajeno que no constituye morada. En este caso, les corresponderá una multa de seis a doce meses, en lugar de tres a seis meses como prevé ahora el artículo 245.2 CP y la sanción será de prisión si usan fuerza en las cosas. Esta realidad engloba también a un grupo de sujetos en situación precaria que no van a los servicios sociales debido a su adicción al alcohol o a las drogas, o porque son inmigrantes irregulares y temen ser expulsados, de manera que, al no agotar todos los recursos, no se les aplica la eximente de estado de necesidad.

Sin embargo, este aumento penológico no responde a los motivos preventivos señalados, pues los casos en que el inmueble se use para actividades delictivas, o un mediador facilite la ocupación con ánimo de lucro se regulan en tipos agravados distintos de esa modalidad básica.

Pues bien, a diferencia de la Proposición del Grupo Parlamentario Popular, se apuntan las verdaderas razones de la reforma: "el retraso y la saturación de los juzgados, que impide que estos delitos leves sean castigados porque, en el momento de proceder a su enjuiciamiento, a menudo ya han prescrito". Por eso, "se prevé una pena de multa superior a los tres meses que..., permitirá que el delito de usurpación del artículo 245 
prescriba a los cinco años y no al año, como ocurre ahora”. Además, se subraya la reforma procesal consistente en incluir este ilícito en el juicio rápido ${ }^{158}$.

El aumento de la multa del artículo 245.2 CP tiene como finalidad, pues, convertir este delito leve en menos grave, para salvar los efectos derivados de las deficiencias del sistema judicial, impidiendo que prescriba $^{159}$, además de posibilitar el enjuiciamiento rápido y la adopción de medidas cautelares. Pero huelga decir que para evitar la prescripción de los delitos lo procedente no es aumentar su pena sino dotar de los medios adecuados al orden jurisdiccional ${ }^{160}$.

En consecuencia, me parece evidente que esta propuesta vulnera las exigencias de proporcionalidad y necesidad derivas del principio de prohibición de exceso ${ }^{161}$, en relación con el derecho a la libertad del artículo $1 \mathrm{CE}^{162}$. No se prevé una pena mayor ateniendo a la gravedad de

158 Puede consultarse una postura favorable a este Proyecto en, MAGRo SERVET, V., "La inminente reforma civil y penal en materia de "okupación» de inmuebles", en Diario La Ley, n $^{\circ}$ 9204, Sección Doctrina, 24 de mayo de 2018, pp. 1 y ss.

159 No hay que olvidar que, como pone de relieve VIVES ANTón, la prescripción y los preceptos que la regulan, afectan al derecho a la libertad del artículo 17 CE. VIVES ANTón, T.S., Fundamentos del sistema penal, 2a edición, Tirant lo Blanch, Valencia, 2011, p. 719.

160 Precisamente, los ciudadanos manifiestan su preocupación por la excesiva lentitud de la justicia y la achacan a la insuficiencia de recursos con que cuenta el sistema judicial. García EsPaÑa, E./DíEz RIPOllÉs, J.L., La administración de justicia según los datos, Instituto Andaluz Interuniversitario de Criminología, Málaga, 2013, pp. 16 y 17.

161 Cuerda ArNau, M.L., "Aproximación al principio de proporcionalidad en Derecho penal”, en VVAA., Estudios jurídicos en memoria del Prof. Dr. D. José Ramón Casabó Ruiz, Vol. I, cit., pp. 452 y ss. Véase, también, ARroyo Zapatero, L.A., "Derecho penal y Constitución”, en Demetrio Crespo, E./Rodríguez Yagüe, C. (coords.), Curso de Derecho penal. Parte general, cit., pp. 143 y ss.; Совo Del Rosal, M./Vives Antón, T.S., Derecho penal. Parte general, cit., pp. 81 y ss.; MIR PUIG, S., "El principio de proporcionalidad como fundamento constitucional de límites materiales del Derecho penal”, en CARBOnELL MATEU, J.C./ González Cussac, J.L./Orts Berenguer, E. (dirs.)/Cuerda Arnau, M.L. (coord.), Constitución, derechos fundamentales y sistema penal, Tomo II, Tirant lo Blanch, Valencia, 2009, pp. 1357 y ss.; Silva SÁnchez, J.M., Aproximación al Derecho Penal contemporáneo, Bosch, Barcelona, 1992, p. 267; y, Silva SÁnchez, J., La expansión del Derecho Penal. Aspectos de la politica criminal en las sociedades postindustriales, Civitas, Madrid, 2001, p. 25.

162 Es cierto que el Tribunal Constitucional ha señalado que, al ponderar la pena proporcionada al delito concreto, el legislador puede tener en cuenta las posibilidades fácticas de su detección y sanción. Pero estas posibilidades han de estar encaminadas a la prevención general y especial y han de ponderarse cuando, de acuerdo con el principio de subsidiariedad emanado del de proporcionalidad, los bienes jurídicos no puedan protegerse por otras vías menos gravosas que el Derecho penal. "Cualquier tacha de desproporción en esta sede y, en general, en jurisdicción de declaración de inconstitucionalidad debe partir inexcusablemente "del recuerdo de la potestad exclusiva del legislador para configurar los bienes penalmente protegidos, los comportamientos penalmente reprensibles, el tipo y la cuantía de las sanciones penales, y la proporción entre las conductas que pretende evitar y las penas con las que intenta conseguirlo". En el ejercicio de dicha potestad "el legislador goza, dentro de los límites establecidos en la Constitución, de un amplio margen de libertad que deriva de su posición constitucional y, en última instancia, de su específica legitimidad democrática (...). De ahí que, en concreto, la relación 
la conducta y para alcanzar el objetivo perseguido, de evitar la prescripción, juzgar a los responsables y, en definitiva, tutelar la posesión, no es indispensable esa intensificación de la intervención penal ${ }^{163}$. Se endurece la respuesta a un delito que hoy ya me parece cuestionable desde el principio de intervención mínima ${ }^{164}$, máxime teniendo en cuenta que se creó una infracción administrativa aplicable a la ocupación sin título.

Por otra parte, ese incremento no afecta solo a la pena de multa, puesto que algunos supuestos hasta ahora incluidos en el artículo 245.2 CP se contemplan en tipos agravados, castigados con prisión ${ }^{165}$.

Así ocurre, en primer lugar, cuando la ocupación del inmueble, vivienda o edificio ajenos se realiza con fuerza en las cosas, que conlleva una pena de prisión de uno a dos años, además de las que correspondan por las violencias ejercidas. Con la introducción de esta conducta independiente se quieren castigar más duramente casos habituales, como la entrada forzando la cerradura, o rompiendo el candado. Es indudable que no cabe entender la fuerza en las cosas en el sentido normativo establecido para

de proporción que deba guardar un comportamiento penalmente típico con la sanción que se le asigna será el fruto de un complejo juicio de oportunidad" que no supone una mera ejecución o aplicación de la Constitución, y para el que "ha de atender no sólo al fin esencial y directo de protección al que responde la norma, sino también a otros fines legítimos que puede perseguir con la pena y a las diversas formas en que la misma opera y que podrían catalogarse como sus funciones o fines inmediatos a las diversas formas en que la conminación abstracta de la pena y su aplicación influyen en el comportamiento de los destinatarios de la norma -intimidación, eliminación de la venganza privada, consolidación de las convicciones éticas generales, refuerzo del sentimiento de fidelidad al ordenamiento, resocialización, etc.- y que se clasifican doctrinalmente bajo las denominaciones de prevención general y de prevención especial. Estos efectos de la pena dependen a su vez de factores tales como la gravedad del comportamiento que se pretende disuadir, las posibilidades fácticas de su detección y sanción, y las percepciones sociales relativas a la adecuación entre delito y pena". STC 161/1997, de 2 de octubre (F.J.9). Ampliamente, Совo Del Rosal, M./Vives AnTón, T.S.: Derecho penal. Parte general, cit., pp. 83 y ss.; LaSCuRAín SÁNCHEZ, J.A., "La proporcionalidad de la norma penal", en Cuadernos de Derecho Público, no 5, 1998, pp. 159 y ss.; Orts Berenguer, E./González Cussac, J.L., Compendio de Derecho penal. Parte general, cit., pp. 137 y ss.; OrTs Berenguer, E./GonZÁlez CussaC, J.L., Introducción al Derecho penal. Parte general, Tirant lo Blanch, Valencia, 2020, pp. 73 y ss.; y, Vives Antón, T. S., La libertad como pretexto, Tirant lo Blanch, Valencia 1995, p. 97.

163 Se trata de uno de los supuestos en que, como apunta LACRUZ LóPEZ, se da sobrepeso a consideraciones mediáticas, en lugar de a las valoraciones técnicas. LACRUZ LóPEZ, J.M., en Gil Gil, A./Lacruz LóPez, J.M./Melendo Pardos, M./Núñez Fernández, J., Curso de Derecho penal. Parte general, 2a edición, Dykinson, Madrid, 2015, p. 14.

${ }_{164}$ Carbonell Mateu pone como ejemplo de vulneración del principio de intervención mínima, por no ser necesaria la tutela penal del bien jurídico, quebrantando la libertad como valor superior de nuestro ordenamiento jurídico, la tutela de la propiedad inmobiliaria más allá de la violencia o el engaño. CaRbonell Mateu, J.C., Derecho penal: concepto y principios constitucionales, Tirant lo Blanch, Valencia, 1995, p. 202.

165 La LO 5/2010, de 22 de junio, elevó la pena, sustituyendo la de multa por la prisión actual. Incluso esta agravación fue criticada por un sector doctrinal. Puede verse, FARALDO Cabana, P., "Los delitos contra el patrimonio tras la reforma de 2010", en La Ley Penal, ${ }^{\circ}$ 81, 2011, p. 16. 
el delito de robo en el artículo $238 \mathrm{CP}$, haciendo una aplicación analógica prohibida por el artículo 4.1 CP. Por consiguiente, de acuerdo con su significado semántico, implica el uso de violencia física en las cosas ${ }^{166}$. Pero lo usual es que los pisos o locales estén cerrados y se emplee algún tipo de fuerza para acceder, de manera que esta pena de prisión se convertiría en habitual en las ocupaciones sin justo título.

Esa penalidad me parece desproporcionada, en tanto es la misma que se prevé en el artículo 245.1 CP para la ocupación realizada con violencia o intimidación, puesto que este precepto se mantiene en la Proposición de Ley. Por otra parte, la fijación de un mínimo de prisión de un año, igual al establecido para el delito de robo con fuerza, que conlleva un apoderamiento definitivo de patrimonio ajeno, también creo que es excesivo.

La pena de prisión se mantendrá, incluso, si la ocupación con fuerza en las cosas queda en grado de tentativa. De acuerdo con la regulación actual cuando se aprecia esta forma imperfecta de ejecución, la sanción máxima es de tres meses menos un día de multa, de modo que, si no se paga cabe sustituirla por localización permanente o trabajos en beneficio de la comunidad y evitar la prisión, al tratarse de un delito leve. Según la propuesta planteada la prisión resultaría ineludible, aunque no se consume la conducta, puesto que el mínimo para la tentativa sería prisión de seis meses y un día, o de tres meses y un día, según se rebaje la pena en uno o dos grados.

En segundo lugar, también se agrava la pena si el que cometiere el delito de ocupación sin justo título, lo hiciere con la finalidad de utilizar el inmueble, vivienda o local para otras actividades delictivas. La sanción es de prisión de seis meses a un año y multa de seis a doce meses, sin perjuicio de las procedentes por los delitos conexos. Se anticipa la barrera de protección, castigando más duramente a quien realiza la acción con una intención determinada, pues para colmar el tipo no se requiere que se inicien esas actividades.

En tercer lugar, se introduce una modalidad cualificada para quienes actúen como mediadores e intermediarios con ánimo de lucro, aplicándoles una pena de prisión de uno a dos años y multa de seis meses a un año, sin perjuicio de las derivadas de las violencias en su caso ejercidas para posibilitar la ocupación. Por lo tanto, se fija igual pena de prisión que para la ocupación con violencia o intimidación en las personas del artículo 245.1 CP, añadiendo además la de multa. Considero que este castigo es desmesurado.

166 Según el Diccionario de la RAE, "forzar" significa "hacer fuerza o violencia física para conseguir algo que habitualmente no debe ser conseguido por la fuerza”. Forzar una puerta. 
Cuando ese mediador o intermediario forme parte de un grupo $\mathrm{u}$ organización criminal, se le impondrán las penas correspondientes por dicha pertenencia y, por el de delito de mediación para la ocupación, prisión de dos a cuatro años y multa.

De esta forma, se incrementa sustancialmente la sanción del delito de mediación en la ocupación por pertenecer el autor a un grupo u organización criminal y, además, se mantiene la del delito de pertenencia a dichos grupos u organizaciones, incurriendo en una flagrante violación del principio non bis in ídem. La solución en este caso habría de ser un concurso de normas entre el nuevo tipo agravado y el delito de pertenencia a grupo u organización criminal de los artículos 570 bis y 570 ter CP. Así lo dispone el artículo 570 quáter, número 2, párrafo segundo CP: "En todo caso, cuando las conductas previstas en dichos artículos estuvieren comprendidas en otro precepto de este Código, será de aplicación lo dispuesto en la regla 4a del artículo 8" 167 . Luego, debería suprimirse la cláusula que establece que el autor será castigado, "además de con las penas en que incurriere por dicha pertenencia", con las previstas en esta modalidad cualificada, dejando únicamente esta penalidad mayor.

Así pues, aunque la creación de nuevos tipos es acorde con el principio de prohibición de exceso, por cuanto corresponde al legislador decidir qué conductas castiga, muchas de las sanciones previstas en la Proposición de Ley me parecen desproporcionadas.

En cambio, esa legitimidad no se da respecto al incremento penológico de la figura tradicional de ocupación pacífica de inmuebles del artículo 245.2 CP. En este caso, la modalidad menor, de acceso sin fuerza

167 En este sentido se pronuncia la STS 132/2019, de 12 de marzo, en relación con el tipo agravado del artículo 369 bis CP: "El artículo 570 bis $1 \mathrm{CP}$ equipara punitivamente a quienes participan activamente en la organización con los que forman parte de ella o cooperaran económicamente o de cualquier otro modo... El nuevo subtipo agravado de organización previsto en el artículo 369 bis CP suscita complejos problemas concursales con la nueva regulación de las organizaciones criminales en el artículo 570 bis, dada la posibilidad de que se dé un concurso de normas entre el nuevo subtipo agravado de organización (art. 369 bis), de una parte, y de otra el concurso real del delito contra la salud pública (arts. 368 y 369 CP) con el nuevo tipo de organización criminal, con sus relevantes agravaciones específicas de penas (art. 570 bis, apartados 1 y 2). Tal concurso de normas habrá de dirimirse con arreglo al artículo 570 quáter.2, aplicando el supuesto que tenga asignada una mayor pena (art. 8.4 CP)" (F.J.2). Asimismo, la STS 495/2015, de 29 de junio, estima el recurso y aplica el artículo 570 ter CP, en lugar del artículo 369.1.2 ${ }^{\mathrm{a}} \mathrm{CP}$, vigente en el momento de los hechos (que agravaba la pena cuando "El culpable perteneciere a una organización o asociación, incluso de carácter transitorio, que tuviese como finalidad difundir tales sustancias o productos aun de modo ocasional"), por resultar el artículo 570 ter CP más beneficioso (F.J.41). Y, la STS 982/2016, de 11 de enero, afirma que concurrían los requisitos del artículo 570 bis CP, por más que el tribunal aplicara el artículo 369 bis CP (F.J.6). Pueden consultarse, también, las SSTS 41/2017, de 31 de enero (F.J.8), y, 510/2020, de 15 de octubre (F.J.3). 
en las cosas, se castiga con multa de seis a doce meses, dejando de ser un delito leve y pasando a ser menos grave.

Según el Grupo proponente con este cambio pretende evitar que estas acciones prescriban y no puedan enjuiciarse, además de disponer su tramitación por el juicio rápido y de facilitar la adopción de medidas cautelares para la reintegración inmediata del inmueble ${ }^{168}$. Pero esa modificación, como he dicho, es contraria al principio de prohibición de exceso y a la máxima de la libertad que preside nuestro Estado social y democrático de Derecho, puesto que el ordenamiento punitivo se emplearía para objetivos distintos a los fines preventivos que le son propios.

\section{Conclusiones}

Como se observa, se ha producido un marcado cambio de tendencia, desde las propuestas despenalizadoras que se formularon en los primeros años de vigencia del Código penal, a las más recientes que optan por un endurecimiento del régimen previsto en el artículo 245.2 CP. Estas posturas represivas se deben en parte al auge de estas acciones, sobre todo en algunas ciudades, pero también a ciertos comportamientos abusivos que han surgido aprovechando el fenómeno de las ocupaciones. Lo cierto es que en su origen estas conductas respondían a motivos económicos o reivindicativos, pero no se vivía la dramática problemática más tarde extendida de hacer de esas prácticas un negocio. Junto a esos supuestos iniciales, que gozan de cierto refrendo social, hoy se dan otros verdaderamente censurables, en que el ocupante, normalmente miembro de una banda organizada, se establece en la vivienda para después coartar al propietario a pagar una suma a cambio de recobrarla. Igualmente proliferan las empresas que ofrecen sus servicios al titular para desalojar a quien la habita ilegítimamente, evitándole la espera e incomodidad de un proceso. A ello se suma que a veces quienes se instalan en el inmueble lo dedican a realizar actuaciones delictivas.

Como es natural, a la ciudadanía le parecen más reprochables esas tramas urdidas con el único propósito de obtener una rentabilidad económica, que la actuación de aquellas personas, que, ante la insuficiencia de medios para conseguir un techo, o por móviles solidarios cometían el delito, al igual que la implicación de empresas que "cumplen" la función de la justicia. Pero, sobre todo, acentúa la alarma social el aumento de la delincuencia en algunos barrios y que los vecinos achacan a quienes se establecen ilícitamente en pisos y locales. A ello se suma que en el ordenamiento civil la Ley 5/2018, de 11 de junio, deja fuera de

168 Se modifica el artículo 795.1.2 $2^{\mathrm{a}}$ LECrim sometiendo al juicio rápido los delitos de usurpación previstos en el artículo 245 CP. 
su ámbito de aplicación a las entidades privadas con ánimo de lucro, por lo que están aumentando significativamente las ocupaciones de viviendas de bancos y grupos inversores, que se ven abocados al proceso penal. Y en este orden se ha iniciado una línea permisiva que niega la realización del delito si la compañía titular no ha dado signos de haber empleado el bien. De modo que crece la indignación ciudadana respecto a los autores y, a la vez, la de las sociedades propietarias que se sienten desprotegidas ante esas infracciones.

Pese a todo, a mi modo de ver la solución no pasa, desde luego, por endurecer la pena de la ocupación de inmuebles sin justo título, sino por arbitrar medios realmente eficaces para devolver la posesión material al titular, ya sea un particular o una persona jurídica. Como decía, tanto el arrendatario que deja de pagar la renta, como el precarista que se mantiene en el inmueble contra la voluntad de su dueño se encuentran, en ese momento, en una posición ilegítima semejante a la del ocupante. Por eso, creo que se debería eliminar el paralelismo que se establece con el delito de allanamiento de morada, en el que se sanciona la entrada y el mantenimiento en ella contra la voluntad del morador, porque en este caso lo que se tutela es la intimidad. En cambio, la posibilidad real de uso y disfrute del inmueble se ve igualmente perjudicada tanto si ha habido autorización inicial para ocuparlo como si se utiliza desde el principio de forma ilícita. Sin embargo, en el primer supuesto se acude al orden civil, mientras el segundo da lugar a un delito del artículo 245.2 CP. Indudablemente, los propietarios no han de asumir la carga de ceder la posesión a quien no puede costearse una vivienda, porque la Constitución atribuye la competencia en estas situaciones a las administraciones públicas. Pero el tratamiento de estos hechos y la reintegración de los inmuebles se pueden hacer a través de las normas civiles y administrativas, que han de ser preferentes al Derecho penal.

Por otra parte, si es posible lograr esa finalidad al margen del ordenamiento punitivo, su aplicación no es necesaria, como se ha dicho, por razones de prevención general. Si en la legislación civil se prevén las disposiciones adecuadas para agilizar el lanzamiento y la pronta recuperación de la vivienda, seguramente esta normativa ejercerá un efecto disuasorio tanto frente al ocupante concreto como respecto a los ciudadanos que se planteen esta solución por su inmediatez frente al recurso a los servicios sociales. A ello se suma, además, la infracción administrativa y la consiguiente multa. En consecuencia, el principio de intervención mínima determina la procedencia de acudir a otras ramas del Derecho.

Tampoco la repetida ineficacia de los mecanismos civiles previstos hasta ahora sirve, a mi juicio, como justificación para mantener un delito sumamente cuestionado. En primer lugar, porque esas medidas pueden mejorarse mediante las oportunas reformas legales, sustantivas y procesales. Y, en segundo lugar, porque la anhelada celeridad en la recuperación del inmueble topa, en todo caso, tanto en la jurisdicción civil 
como en la penal, con el derecho a la tutela judicial efectiva que el TEDH reconoce a quien se encuentra en la propiedad y alega su derecho de uso. Como se ha visto, esto suele ser lo normal, porque quien se instala en ella cambia la cerradura, coloca objetos personales que dan la apariencia de pertenencia o consigue un contrato falso. En todos estos casos, en los que la ilegalidad no es clara, según la Corte europea no se debe realizar la expulsión y hay que esperar al juicio. De manera que el proceso penal no proporciona una mayor rapidez y no puede descansar en ella su eficacia preventiva.

Por otra parte, se podría alegar que, si se dan los presupuestos, se apreciará la eximente de estado de necesidad y se absolverá a la persona acusada. Pero ya se habrá visto inmersa en un procedimiento criminal, con los consabidos inconvenientes que ello conlleva. Además, en este delito en particular su aplicación se supedita a una condición formal, consistente en la solicitud previa de ayuda a los servicios sociales, de modo que si esta petición no se formula se rechaza la exención y se declara el delito, aun constatándose el estado de pobreza.

A mi modo de ver, se ha enfatizado, sobre todo por los medios de comunicación, el incremento exponencial del número de viviendas ilegalmente usurpadas desatando una importante preocupación social, pero sin deslindar debidamente dos situaciones enteramente distintas, que desde luego no merecen el mismo reproche y deben ser objeto de un tratamiento diferente. Se lee en las sentencias condenas a familias que viven verdaderos dramas y a quienes se aplica el delito porque no han acudido antes a los servicios públicos. Frente a estos supuestos, están los de quienes se lucran realizando una ocupación y chantajeando al propietario para liberar el inmueble, así como aquellos que los utilizan para actividades ilícitas.

En estos casos deben perseguirse los delitos asociados a la ocupación, que, por cierto, son los que provocan una mayor indignación y revuelo social. Pero al margen de esas eventuales infracciones que atañen a otros bienes jurídicos, la mera utilización de un inmueble ajeno, que no constituye morada y sin emplear violencia ni intimidación debe resolverse, como digo, a través de las demás ramas del Derecho.

\section{Bibliografía}

Álvarez Tejero, A.: "La usurpación delito leve o infracción administrativa. "A vueltas con el art.245.2 del Código Penal», en Lefebvre-El Derecho, $\mathrm{n}^{\circ}$ 2, 13 de julio 2016 (https://elderecho.com/la-usurpaciondelito-leve-o-infraccion-administrativa-a-vueltas-con-el-art-245-2-delcodigo-penal-2). 
ARIAs EIBE, M.J.: "La inviolabilidad del domicilio: dimensión constitucional y protección penal”, en Diario La Ley, Sección Doctrina, Tomo IV, 2001.

Arroyo Zapatero, L.A.: “Derecho penal y Constitución”, en Demetrio Crespo, E./Rodríguez Yagüe, C. (coords.): Curso de Derecho penal. Parte general, $3^{\mathrm{a}}$ edición, Ediciones Experiencia, Barcelona, 2016.

Barja De Quiroga, J., en Barja De Quiroga, J./Granados Pérez, C.: Manual de Derecho penal. Parte especial. Tomo II. (Contestaciones al programa de Derecho Penal Parte Especial para acceso a las carreras Judicial y Fiscal. Temas 27 a 63), Aranzadi, Navarra, 2018 (E-book).

Baucells I Lladós, J.: La ocupación de inmuebles en el Código penal de 1995, Tirant lo Blanch, Valencia, 1998.

Baucells I Lladós, J., en Córdoba Roda, J./Garcia Arán, M.: Comentarios al Código Penal. Parte Especial, Tomo I, Marcial Pons, Madrid 2004.

Berdugo De La Torre, I.: “El Derecho penal”, en Demetrio Crespo, E./ Rodríguez Yagüe, C. (coords.): Curso de Derecho penal. Parte general,

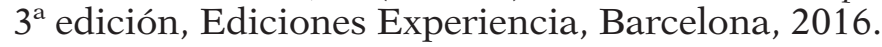

BoRJA JiMÉNEZ, E.: "El bien jurídico protegido en el delito de allanamiento de morada”, en VVAA: Estudios jurídicos en memoria del Prof. Dr. D. José Ramón Casabó Ruiz, Vol I, Universitat de València, 1997.

Baucells I Lladós, J., en González Cussac, J.L. (coord.): Derecho penal. Parte especial, Tirant lo Blanch, Valencia, 2019.

CÁmARA ARroyo, S.: “Justicia Social y Derecho penal: individualización de la sanción penal por circunstancias socioeconómicas del penado (arts. 66.1.6, 20.7 CP y 7.3 LORRPM)", en ADPCP, Vol. LXVIII, 2015.

Carbonell Mateu, J.C.: Derecho penal: concepto y principios constitucionales, Tirant lo Blanch, Valencia, 1995.

CARrillo Fuillerat, D.A.: "Procedimientos que llevan aparejado el lanzamiento", en Diario La Ley, n ${ }^{\circ}$ 9289, Sección Doctrina, 30 de octubre de 2018.

Casas Villa, J.: "Reflexiones en torno al delito de usurpación pacífica de inmuebles", en Diario La Ley, no 9709, Sección Tribuna, 5 de octubre de 2020.

Cobo Del Rosal, M.: “La nueva concepción del delito de usurpación”, en Lawyerpress News, 18 de febrero de 2014 (https://www.lawyerpress. com/news/2014_02/delito_de_usurpación.html).

Cobo Del Rosal, M./Vives Antón, T.S.: Derecho penal. Parte general, Tirant lo Blanch, Valencia, 1999.

CuERDA ARNAU, M.L.: "Aproximación al principio de proporcionalidad en Derecho penal”, en VVAA: Estudios jurídicos en memoria del Prof. Dr. D. José Ramón Casabó Ruiz, Vol. I, Universitat de València, 1997. 
De La Mata Barranco, N.J.: "El inexistente plazo de 48 horas: la policía no tiene límite de tiempo para intervenir en una okupación”, en Diario El País, 1 de septiembre de 2020 (https://verne.elpais.com/verne/2020/09/01/articulo/1598938999_179935.html).

DíEz Ripollés, J.L.: “Algunos rasgos de la delincuencia en España a comienzos del siglo XXI”, en Revista Española de Investigación Criminológica, Artículo 1, n 4, 2006 (https://dialnet.unirioja.es/servlet/ articulo?codigo $=2083343$ ).

FARAldo Cabana, P.: "Los delitos contra el patrimonio tras la reforma de 2010”, en La Ley Penal, no 81, 2011.

Faraldo Cabana, P.: Los delitos leves. Causas y consecuencias de la desaparición de las faltas, Tirant lo Blanch, Valencia 2016.

FERNÁNDEZ APARICIO, J.M.: “Comentario al artículo 245 párrafo 20”, en Diario La Ley, Sección Doctrina, Tomo 4, 1997.

Gallego Soler, J.I., en Corcoy Bidasolo, M./Mir Puig, S. (dirs.): Comentarios al Código penal. Reforma LO 1/2015 y LO 2/2015, Tirant lo Blanch, Valencia, 2015.

GARcía EsPaÑA, E./DíEz RIPOLLÉs, J.L.: La administración de justicia según los datos, Instituto Andaluz Interuniversitario de Criminología, Málaga, 2013.

García España, E./Díez Ripollés, J.L./PÉRez Jiménez, F./Benítez Jiménez, M.J./CERezo Domínguez, A.: "Evolución de la delincuencia en España: análisis longitudinal con encuestas de victimización”, en Revista Española de Investigación Criminológica, Artículo 2, nº 8, 2010 (https:// dialnet.unirioja.es/servlet/articulo?codigo=3187503).

García OrRuÑo, A.: “Cuestiones procesales que plantea la Ley 5/2018, de 11 de junio, en materia de ocupación ilegal”, en Boletín Juezas y Jueces para la Democracia, 19 de diciembre de 2018.

GASCA LóPEZ, A.I.: "Análisis de elementos diferenciadores de delitos menos graves y leves”, en Cuadernos Digitales de Formación, n 45, 2017.

Gómez IBARguren, P.: "El fenómeno okupa desde la perspectiva del Derecho penal”, en Noticias Jurídicas, 1 de noviembre de 2007 (https:// noticias.juridicas.com/conocimiento/articulos-doctrinales/4326-elfenomeno-okupa-desde-la-perspectiva-del-derecho-penal/).

GonZÁLEZ Rus, J.J.: "Secuelas «colaterales» no pretendidas de la LO 1/2015, de 30 de marzo, de reforma del Código Penal”, en Diario La Ley, no 8553, Sección Tribuna, 3 de junio de 2015.

González Rus, J.J., en Morillas Cueva, L. (dir.): Estudios sobre el Código penal reformado (Leyes Orgánicas 1/2015 y 2/2015), Dykinson, Madrid, 2015.

GuILlÉN Álvarez, I.: "Estudio y análisis jurídico de la nueva Ley Orgánica 4/2015, de protección de la seguridad ciudadana”, en Diario La Ley, $\mathrm{n}^{\mathrm{o}}$ 8633, Sección Doctrina, 27 de octubre de 2015. 
HERNÁNDEZ GARcíA, J.: "La protección constitucional de la vivienda y su proyección penal: especial referencia a los movimientos okupa y mobbing inmobiliario", en Cuadernos de Derecho Judicial, X, 2005.

HERNÁNDEZ GARCÍA, J./RAMÍREz ORTIZ, J.L.: "Las consecuencias procesales de la reforma", en Quintero Olivares, G. (dir.): Comentario a la reforma penal de 2015, Aranzadi, Navarra, 2015.

Herranz Castillo, R., "Desobediencia civil, ocupación y derecho a la vivienda”, en Actualidad Jurídica Aranzadi, n 435, 2000.

HidAlgo García, J.: "Hacia un protocolo de actuación integral en materia de ocupaciones de viviendas y bienes inmuebles", en Diario La Ley, $\mathrm{n}^{\circ}$ 9719, Sección Tribuna, 20 de octubre de 2020.

Huerta Tocildo, S.: Protección penal del patrimonio inmobiliario, Civitas, Madrid, 1980.

IzQuiERdo Téllez, C.: “¿Se puede detener por delito leve?”, en Diario La Ley, n 8582, Sección Tribuna, 14 de julio de 2015.

Jiménez París, J.M.: La ocupación de inmuebles en el Código penal español, Reus, Madrid, 2018.

JiMÉNEZ PARÍs, J.M.: "Desahucio exprés contra la ocupación de viviendas", en Diario La Ley, n 9262, Sección Doctrina, 19 de diciembre de 2018.

Jiménez SEgado, C.: “¿Es delictiva la ocupación pacífica y sin autorización de un inmueble, vivienda o edificio ajenos que no constituyan morada?", en La Ley Penal, n ${ }^{\circ}$ 102, Sección Consulta de los suscriptores, La Ley 577/2013.

Lacruz López, J.M., en Gil Gil, A./Lacruz LóPez, J.M./Melendo Pardos, M./NúÑEz FERnÁndez, J.: Curso de Derecho penal. Parte general, $2^{\mathrm{a}}$ edición, Dykinson, Madrid, 2015.

LASCURAín SÁnchez, J.A.: "La proporcionalidad de la norma penal”, en Cuadernos de Derecho Público, no 5, 1998.

LóPEz GarRido, D./GARcía ARÁN, M.: El Código penal de 1995 y la voluntad del legislador. Comentario al texto y al debate parlamentario, Madrid, 1996.

Magro Servet, V.: "Ocupación ilegal de inmuebles: ¿delito del art. 245.2 CP o precario?, en La Ley Penal, nº 85, septiembre 2011.

Magro SERVET, V.: "Soluciones ante la presencia de okupas, pisos patera y defraudación de fluido eléctrico en las comunidades de vecinos. ¿Cómo actuar ante alquileres irregulares u ocupación de viviendas y los enganches ilegales de luz a vecinos?”, en Diario La Ley, no 8225, Sección Tribuna, 9 de enero de 2014.

Magro Servet, V.: "El delito de ocupación de inmuebles del art. 245.2. ¿Vía penal o vía civil?”, en La Ley Penal, n 126, mayo-junio 2017.

Magro Servet, V.: "La inminente reforma civil y penal en materia de «okupación» de inmuebles", en Diario La Ley, n 9204, Sección Doctrina, 24 de mayo de 2018. 
Magro Servet, V.: "Análisis de los títulos de oposición de los «okupas» ante demandas por la vía del art. 441 bis $2^{\circ}$ LEC”, en Diario La Ley, $\mathrm{n}^{\circ}$ 9419, Sección Doctrina, 21 de mayo de 2019.

Magro Servet, V.: “¿Delito de ocupación de morada (art. 245.2 CP) o allanamiento de morada (art. 202 CP) ¿Medidas civiles o medidas cautelares penales de expulsión?, en Diario La Ley, n 9680, Sección Doctrina, 23 de julio de 2020.

MANGas CAmpos, Á.: "La interpretación del artículo 245.2 del Código Penal y el activismo judicial”, en Diario La Ley, n ${ }^{\circ} 8672$, Sección Doctrina, 28 de diciembre de 2015.

Manzanares Samaniego, J.L.: Comentarios al Código penal (Tras las Leyes Orgánicas 1/2015, de 30 de marzo y 2/2015, de 30 de marzo), La Ley, Madrid, 2016.

Marín De Espinosa Ceballos, E., En Zugaldía Espinar, J.M. (dir.)/MoRENo Torres-Herrera, M.R. (coord.): Fundamentos de derecho penal. Parte general, Tirant lo Blanch, Valencia, 2015.

Martí MARTí, J.: "La protección del Derecho penal frente a la ocupación de los bienes inmuebles por colectivos «ocupas»", en Diario La Ley, $\mathrm{n}^{\circ}$ 7999, Sección Tribuna, 11 de enero de 2013.

Martínez García, A.S., en Gómez Tomillo, M.: Comentarios prácticos al Código penal. Delitos contra el patrimonio y socieconómicos, Tomo III, Aranzadi, Navarra, 2015.

Mestre Delgado, E., en Lamarca Martínez, C. (coord.): Delitos. Parte especial del Derecho penal, Dykinson, Madrid, 2020.

MiR PUIG, S.: "El principio de proporcionalidad como fundamento constitucional de límites materiales del Derecho penal”, en CARBONELL MATEU, J.C./GonzÁlez Cussac, J.L./Orts Berenguer, E. (dirs.)/ CuERdA ARNAU, M.L. (coord.): Constitución, derechos fundamentales y sistema penal, Tomo II, Tirant lo Blanch, Valencia, 2009.

Mir Puig, S.: Derecho penal. Parte general, Reppertor, Barcelona, 2015.

MirapeIX LAcASA, N.: "Las ocupaciones de inmuebles por motivos de necesidad”, en Revista Electrónica de Ciencia Penal y Criminología, 20-22, 2018.

Morales Prats, F.: “Comentario al artículo 202 del Código penal”, en Quintero Olivares, G. (dir.)/Morales Prats, F. (coord.): Comentarios al Código penal español, Tomo I, $7^{\text {a }}$ edición, Aranzadi, Navarra, 2016 (E-book).

Muñoz Conde, F.: Derecho penal. Parte especial, Tirant lo Blanch, Valencia, 2017.

Muñoz Conde, F./García ArÁn, M.: Derecho penal. Parte general, Tirant lo Blanch, Valencia, 2015. 
Orts Berenguer, E./González Cussac, J.L.: Compendio de Derecho penal. Parte general, Tirant lo Blanch, Valencia, 2019.

Orts Berenguer, E./GonzÁlez Cussac, J.L.: Introducción al Derecho penal. Parte general, Tirant lo Blanch, Valencia, 2020.

Parejo Alonso, L.: "La deriva de las relaciones entre los Derechos administrativo y penal. Algunas reflexiones sobre la necesaria recuperación de su lógica sistemática", en Documentación Administrativa, Madrid, no 284-285, 2009.

Perea GonzÁlez, Á.: "La recuperación de la vivienda ocupada ilegalmente: un examen del proceso del artículo 250.1.4 de la Ley de Enjuiciamiento Civil”, en Diario La Ley, n 3, 2019.

PÉRez Daudí, V./SÁnchez García, J.: "La protección del propietario frente a los actos de ocupación ilegal de un bien inmueble", en Diario La Ley, n ${ }^{\circ}$ 9008, Sección Documento on-line, 26 de junio de 2017.

PÉREz DAudí, V./SÁnchez García, J.: "La okupación de bienes inmuebles y la protección efectiva del poseedor legítimo”, en Diario La Ley, n ${ }^{\circ}$ 9687, Sección Tribuna, 2 de septiembre de 2020.

Queralt Jiménez, J.J.: Derecho penal español. Parte especial, Atelier, Barcelona, 2010.

Quintero Olivares, G.: La reforma penal de 2010: análisis y comentario, Aranzadi, Navarra, 2010.

Quintero Olivares, G.: “Comentario al artículo 245 del Código penal”, en Quintero Olivares, G. (dir.)/Morales Prats, F. (coord.): Comentarios al Código penal español, Tomo I, 7ª edición, Aranzadi, Navarra, 2016 (E-book).

RAMÓN Rivas, E.: "El delito de ocupación ilegal no violenta de viviendas", en Estudios Penales y Criminológicos, Vol. XL, 2020.

Robles Planas, R./Pastor Muñoz, N., en Silva Sánchez, J.M. (dir.)/RaGuÉs I VAllÈs, R. (coord.): Lecciones de Derecho penal. Parte especial, Atelier, Barcelona, 2015.

RoDRíguEz LAINZ, J.L.: ¿Es jurídicamente posible el desalojo inmediato de viviendas objeto de un delito leve de ocupación ilegal?, en Diario La Ley, nº 9701, Sección Doctrina, 22 de septiembre de 2020.

RoDRÍGUEZ LAINZ, J.L.: "Discrepancias y refutaciones a la Instrucción de la Fiscalía General del Estado 1/2020 sobre medidas cautelares de desalojo de inmuebles ocupados ilegalmente", en Diario La Ley, $\mathrm{n}^{\circ}$ 9709, Sección Doctrina, 5 de octubre de 2020.

Rodríguez Ramos, L. (dir.): Código penal (concordado y comentado con jurisprudencia) y leyes penales especiales y complementarias, La Ley, Madrid, 2015. 
Romeo Casabona, C.M./Sola Reche, E./Boldova Pasamar, M.A.: Derecho Penal. Parte especial, Comares, Granada, 2016.

Rubio Pérez De Acevedo, M.P.: "La usurpación de inmuebles. Estudio del artículo 245.2 del Código Penal", en Revista Jurídica de la Comunidad de Madrid, no 29, 30 de diciembre de 2009 (http://www.madrid. org/revistajuridica/).

Ruiz Blay, G.: "La ineficacia práctica del artículo 245 del Código Penal para obtener el desalojo de un inmueble usurpado", en Diario La Ley, $n^{\circ}$ 8429, Sección Dossier, 26 de noviembre de 2014.

SANZ MoRÁN, Á.: El allanamiento de morada, domicilio de personas jurídicas y establecimientos abiertos al público, Tirant lo Blanch, Valencia, 2006.

SCHUMANN BARRAGÁN, G.: "El proceso de tutela sumaria de la posesión por ocupación ilegal de viviendas introducido por la Ley 5/2018. Su naturaleza jurídica y algunas implicaciones prácticas", en Diario La Ley, $\mathrm{n}^{\circ}$ 9264, Sección Tribuna, 21 de septiembre de 2018.

Serrano Gómez, A./Serrano Maíllo, A.: Derecho penal. Parte especial, 11 edición, Dykinson, Madrid, 2006.

Serrano Gómez, A./Serrano Maíllo, A./Serrano Tárraga, M.D/VázQuez GonzÁlez, C.: Curso de Derecho penal. Parte especial, 4ª edición, Dykinson, Madrid, 2017.

SERrano Maíllo, A.: "Una nueva prueba de la teoría de los sentimientos de inseguridad explicativa de la firmeza frente al delito", en ADPCP, Vol. LXXIII, 2020.

SERRANo-PIEdecasas FERnÁNDEZ, J.R.: "La usurpación", en Cuadernos de Derecho Judicial, XIII, 2004.

Serrano TÁrraga, M.D.: "Exclusión social y criminalidad", en Revista de Derecho de la UNED, n ${ }^{\circ}$ 14, 2014.

Sierra Gabarda, R.: “Ocupación y confusión procesal”, en Diario La Ley, $n^{\circ}$ 9707, Sección Tribuna, 1 de octubre de 2020.

Silva SÁnchez, J.M.: Aproximación al Derecho Penal contemporáneo, Bosch, Barcelona, 1992.

Silva SÁnchez, J.M.: La expansión del Derecho Penal. Aspectos de la política criminal en las sociedades postindustriales, Civitas, Madrid, 2001.

TERRAdillos BAsoco, J. M.: "Las reformas penales españolas de 2003: valoración político-criminal”, en Nuevo Foro Penal, nº 67, 2005.

Tutor Antón, A.: “¡Barcelona okupa! Una posible historia de la okupación en Barcelona”, en Inguruak, n 68, 2020 (http://www.inguruak. eus/index.php/inguruak/article/view/178/105).

Vázouez Iruzubieta, C.: Código penal comentado, Atelier, Barcelona, 2015. 
Vives Antón, T.S.: La libertad como pretexto, Tirant lo Blanch, Valencia 1995.

Vives Antón, T.S.: Fundamentos del sistema penal, $2^{\mathrm{a}}$ edición, Tirant lo Blanch, Valencia, 2011.

Vives Antón, T.S./GonzÁlez Cussac, J.L., en Vives Antón, T.S. (coord.): Comentarios al Código penal de 1995, Vol. II, Tirant lo Blanch, Valencia, 1996. 